University of Nebraska - Lincoln

DigitalCommons@University of Nebraska - Lincoln

\title{
The last interglacial period on the Pacific Coast of North America: Timing and paleoclimate
}

Daniel R. Muhs

U.S. Geological Survey, dmuhs@usgs.gov

Kathleen R. Simmons

U.S. Geological Survey, ksimmons@usgs.gov

George L. Kennedy

San Diego State University

Thomas K. Rockwell

San Diego State University

Follow this and additional works at: https://digitalcommons.unl.edu/usgsstaffpub

Part of the Earth Sciences Commons

Muhs, Daniel R.; Simmons, Kathleen R.; Kennedy, George L.; and Rockwell, Thomas K., "The last interglacial period on the Pacific Coast of North America: Timing and paleoclimate" (2002). USGS Staff -Published Research. 159.

https://digitalcommons.unl.edu/usgsstaffpub/159

This Article is brought to you for free and open access by the US Geological Survey at DigitalCommons@University of Nebraska - Lincoln. It has been accepted for inclusion in USGS Staff -- Published Research by an authorized administrator of DigitalCommons@University of Nebraska - Lincoln. 


\title{
The last interglacial period on the Pacific Coast of North America: Timing and paleoclimate
}

\author{
Daniel R. Muhs* \\ Kathleen R. Simmons \\ U.S. Geological Survey, M.S. 980, Box 25046, Federal Center, Denver, Colorado 80225, USA
}

George L. Kennedy ${ }^{\dagger}$

Thomas K. Rockwell

Department of Geological Sciences, San Diego State University, San Diego, California 92182, USA

\section{ABSTRACT}

New, high-precision U-series ages of solitary corals (Balanophyllia elegans) coupled with molluscan faunal data from marine terraces on the Pacific Coast of North America yield information about the timing and warmth of the last interglacial sea-level highstand. Balanophyllia elegans takes up $\mathrm{U}$ in isotopic equilibrium with seawater during growth and shortly after death. Corals from the second terrace on San Clemente Island (offshore southern California), the third terrace on Punta Banda (on the Pacific Coast of northern Baja California), and the Discovery Point Formation on Isla de Guadalupe (in the Pacific Ocean offshore Baja California) date to the peak of the last interglacial period and have U-series ages ranging from ca. 123 to $114 \mathrm{ka}$. The first terrace on Punta Banda has corals with ages ranging from ca. 83 to $80 \mathrm{ka}$, which corresponds to a sea-level highstand formed in the late last interglacial period. $\mathrm{U}$-series analyses of corals from the Cayucos terrace (central California) and the Nestor terrace at Point Loma (southern California) show that these fossils have evidence of open-system history, similar to what has been reported by other workers for the same localities. Nevertheless, a model of continuous, secondary $U$ and Th uptake shows that two ages of corals are likely present at these localities, representing the ca. 105 and ca. 120 ka sea-level highstands reported elsewhere.

\footnotetext{
*E-mail: dmuhs@usgs.gov.

${ }^{\dagger}$ Mailing address: San Diego Paleontological Associates, 8997 Moisan Way, La Mesa, California 91941, USA.
}

U-series ages of last interglacial corals from the Pacific Coast overlap with, but are on average younger than the ages of corals from Barbados, the Bahamas, and Hawaii. This age difference is explained by the nature of the geomorphic response to sea-level change: fringing or barrier reefs on lowlatitude coastlines have an accretionary growth style that keeps pace with rising sea level, whether on a tectonically rising or stable coastline. In contrast, midlatitude, high-energy coastlines are sites of platform cutting during the early part of a sea-level high stand and terrace scouring and concomitant sediment and fossil deposition as sea level starts to recede. The youngest ages of corals from the Pacific Coast suggest that sea level was still relatively high at ca. 116 ka, which is not in agreement with other estimates of relatively large global ice volume at that time.

Reliably dated, ca. 120 ka marine-terrace deposits on the Pacific Coast have fossil mollusks that indicate water temperatures as warm or warmer than at present. In contrast, ca. 80 ka marine deposits reported here and elsewhere have fossil mollusks indicating cooler-than-modern water temperatures. The presence of both ca. $105 \mathrm{ka}$ and ca. 120 ka corals on the Nestor and Cayucos terraces explains a previously enigmatic mixture of warm-water and cool-water mollusks. At ca. 105 ka, a relatively high sea level with cool waters may have "captured" the terrace formed during the $\mathbf{1 2 0}$ ka sea-level highstand, in areas of low uplift rate.

The inference of cooler-than-modern waters off the Pacific Coast of North America at ca. 80 ka and ca. $105 \mathrm{ka}$, based on ma- rine-terrace faunas, does not agree with estimates of sea-surface temperatures derived from alkenone studies in the Santa Barbara Basin. However, cooler water temperatures at these times are in agreement with paleotemperature estimates from planktonic foraminiferal data for the Santa Barbara Basin. All records, from central California to Baja California, whether from marine terraces or offshore cores, indicate at least seasonably warmer-than-modern waters during the peak of the last interglacial period at ca. 120 ka.

Keywords: corals, marine terraces, Mollusca, Pacific Coast, paleoclimate, sea level, uranium-series method, zoogeography.

\section{INTRODUCTION}

The precise timing, duration, and paleoclimatic conditions of the peak of the last interglacial period (substage $5 \mathrm{e}$ of the marine oxygen isotope record) have been actively debated. Understanding the timing of this warm period is important because it may give crucial information on the likely duration of the present interglacial period (Broecker, 1998; Kukla, 2000). The sea-level record is an important means by which both the duration and warmth of the last interglacial period can be estimated. The Quaternary geologic record of sea-level highstands takes the form of emergent reefs and marine terraces, on either tectonically stable or rising coasts. Corals present in these deposits can be accurately and precisely dated by using U-series methods via thermal-ionization mass spectrometry (TIMS). On coastlines that are neither rising nor subsiding, marine deposits or growth-position

GSA Bulletin; May 2002; v. 114; no. 5; p. 569-592; 20 figures; 1 table; Data Repository item 2002060. 
reef corals will be left as emergent records only during times when sea level was higher-and therefore global ice volume was lower-than at present. Records from Hawaii (Szabo et al., 1994; Muhs et al., 2002), the Bahamas (Chen et al., 1991; Muhs et al., 1994a), and Australia (Zhu et al., 1993; Collins et al., 1993; Stirling et al., 1995, 1998) indicate that the last interglacial sea-level highstand could have begun well before the Northern Hemisphere, high-latitude summer insolation peak at ca. $128 \mathrm{ka}$ and was still high as late as $116 \mathrm{ka}$, when high-latitude summer insolation in the Northern Hemisphere was at its lowest values of the past 200 k.y. This timing of the last interglacial sea-level highstand conflicts with inferences from the deep-sea oxygen isotope record of a considerable volume of global ice at ca. 116 ka (Mix, 1992; Shackleton, 1987; Martinson et al., 1987).

On the slowly uplifting coastline of California and northern Baja California (Fig. 1), marine terraces are prominent landforms (Woodring et al., 1946; Bradley and Griggs, 1976; Kern, 1977; Muhs, 1983; Rockwell et al., 1989, 1992; Lajoie et al., 1991; Kennedy et al., 1992; Kern and Rockwell, 1992; Muhs et al., 1990, 1994b). Marine terraces are emergent, erosional platforms veneered with thin, sometimes fossiliferous, marine sand and gravel. U-series dating of solitary corals from these deposits by alpha spectrometry shows that, to a first approximation, marine terraces on the coast of California correlate with the same high stands of sea level recorded by uplifted reefs on tropical coastlines such as New Guinea, Barbados, and Haiti (Ku and Kern, 1974; Rockwell et al., 1989; Stein et al., 1991; Muhs et al., 1994b).

Erosional landforms such as marine terraces may not form at precisely the same time during a sea-level highstand as constructional coral reefs. What are referred to as "keep-up" reefs of tropical waters are those dominated by shallow-water corals such as Acropora (Neumann and MacIntyre, 1985). Such reefs, found on Barbados, Haiti, and parts of the Bahamas, can keep pace with rapidly rising sea level. Thus, on an emergent coast, these reefs record the early rise of sea level as well as its peak (Fig. 2). On a high-energy, erosional coastline such as that along much of California and northern Baja California, the early part of an interglacial sea-level highstand (e.g., during stage 2 or early stage 3 of Fig. 2) may be dominated by terrace cutting. Fossils left on the platform, therefore, may be those from organisms living in nearshore waters considerably later (e.g., from late stage 3 or stage 4 of Fig. 2), perhaps just before sea-level re-

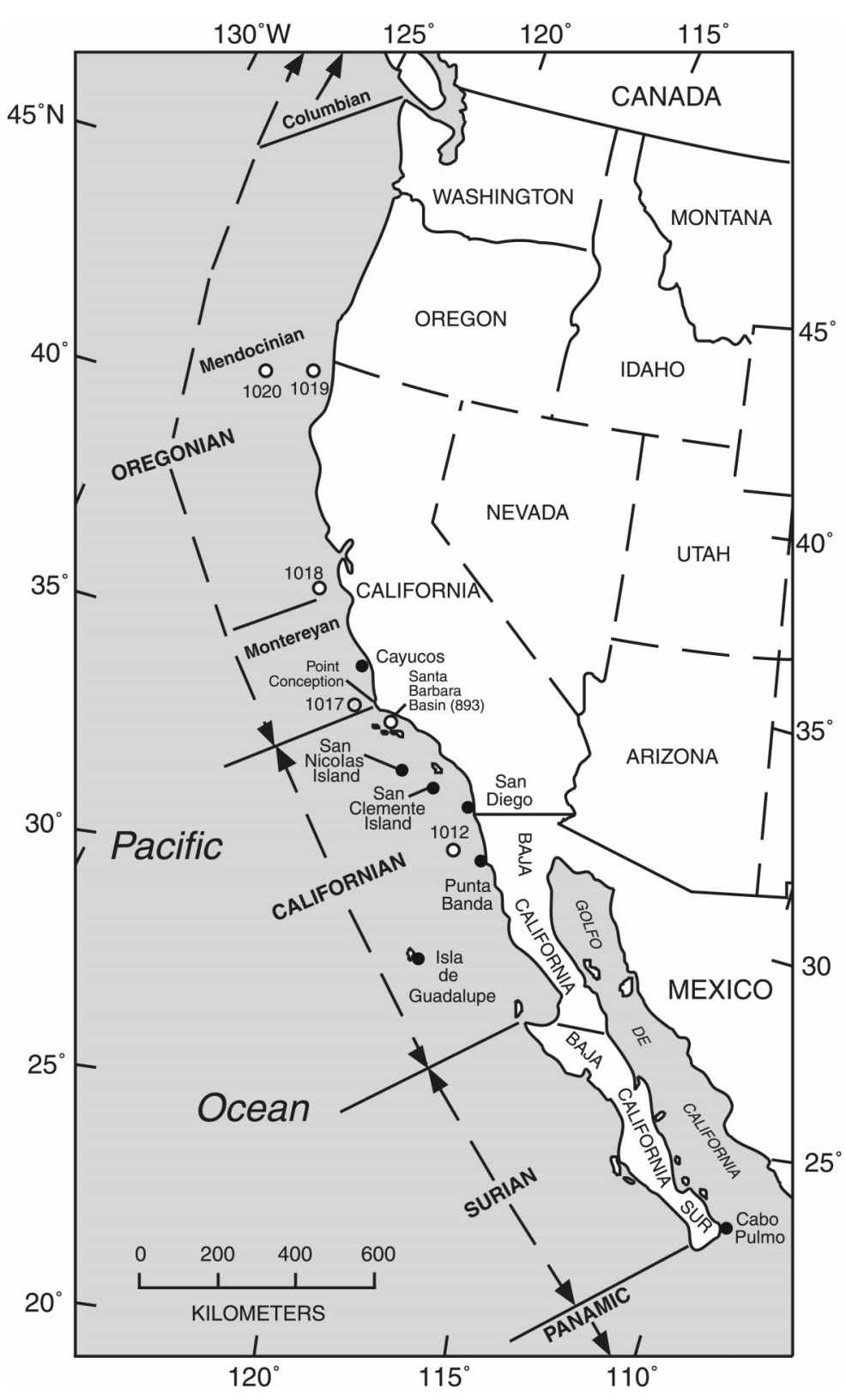

Figure 1. Map showing part of the Pacific Coast of North America and marine-terrace localities studied (solid circles), and ODP (Ocean Drilling Program) localities (open circles with site numbers) referred to in the text. Also shown are the approximate boundaries of molluscan faunal provinces (from Valentine, 1966).

gression. During stage 5 (as shown in Fig. 2), terrace emergence takes place. If this model is correct, California marine-terrace fossils could record the final stages of an interglacial sealevel highstand.

The most comprehensive study of last interglacial sea-surface temperatures is the effort by the CLIMAP group (CLIMAP Project Members, 1984) using foraminifera from deep-sea cores. They concluded that last interglacial ocean temperatures were similar to, or slightly warmer than, present conditions.
However, although this study was global in its extent, few cores were then available from the eastern Pacific Ocean. In the past few years, there have been several new cores raised from localities off the California coast (Fig. 1). We compared paleotemperature estimates from these cores with published molluscan faunas from our marine-terrace localities, using updated zoogeographic information.

In addition to the ca. $120 \mathrm{ka}$ interglacial sea-level highstand, later sea stands at ca. 105 $\mathrm{ka}$ and ca. $80 \mathrm{ka}$ have also been recognized 
A

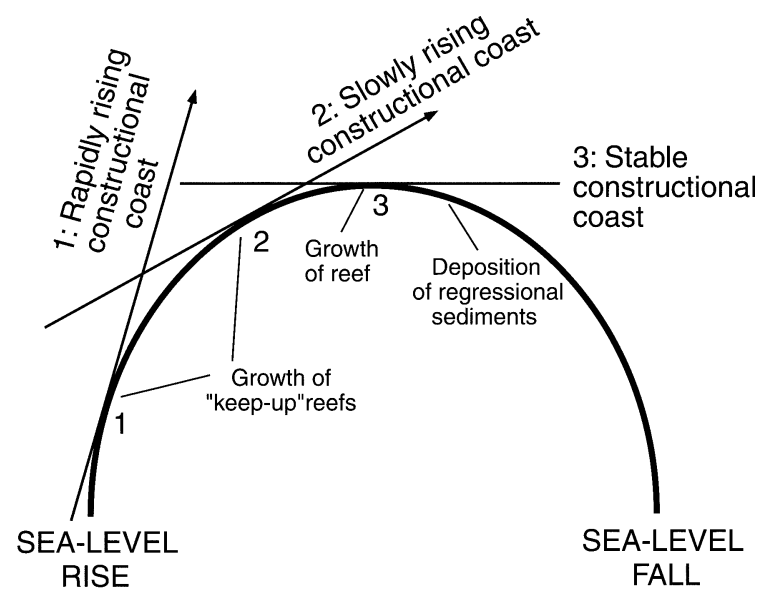

B

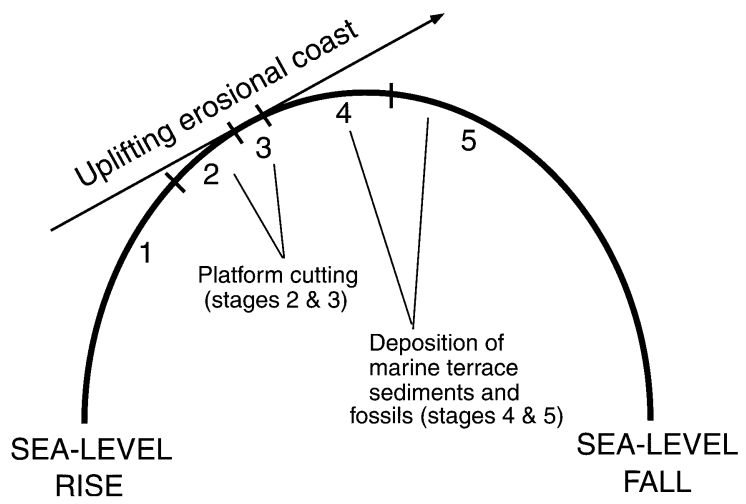

Figure 2. Models of the timing of marine-terrace formation as a function of sea-level highstands during an interglacial period. A: Timing of constructional reef-terrace formation as a function of uplift rate and reef type (modified from Edwards et al. [1987] and Neumann and MacIntyre [1985]). B: Timing of erosional marine-terrace formation, such as that found on the Pacific Coast of North America (from Bradley and Griggs, 1976).

on many coastlines. Work on the record of these sea stands began with reef mapping and alpha-spectrometric U-series ages of corals from what are now referred to as the Ventnor (ca. $105 \mathrm{ka}$ ) and Worthing (ca. $80 \mathrm{ka}$ ) terraces on Barbados (Broecker et al., 1968; Ku, 1968; Mesolella et al., 1969; Bender et al., 1979; Ku et al., 1990). More recent high-precision TIMS U-series analyses of these terraces have confirmed the earlier age estimates (Gallup et al., 1994; Edwards et al., 1997). The same sealevel highstands are recorded as emergent reefs on tectonically rising New Guinea and Haiti (Bloom et al., 1974; Dodge et al., 1983; Chappell and Shackleton, 1986) and also correspond to global ice-volume minima designated as substage $5 \mathrm{c}$ (ca. $105 \mathrm{ka}$ ) and substage $5 \mathrm{a}$ (ca. $80 \mathrm{ka}$ ) of the deep-sea oxygen isotope record (Martinson et al., 1987).

In this study, we test the just-outlined hypotheses of the timing of last interglacial high sea level and sea-surface paleotemperatures by utilizing marine-terrace fossils from localities in California and Baja California. We have dated well-preserved and unrecrystallized marine-terrace corals by U-series methods using TIMS, which yields much higher precision than is possible with alpha-spectrometric methods and also allows analysis of coral individuals. We have used a zoogeographic approach to estimating relative (i.e., warmer or cooler than present) sea-surface temperatures along the Pacific Coast of North America during the last interglacial period (Kennedy et al., 1982, 1992; Kennedy, 2000).

\section{URANIUM-SERIES SYSTEMATICS}

All corals, whether colonial or solitary, take up $U$ in isotopic equilibrium with seawater and frequently behave as closed systems with respect to ${ }^{238} \mathrm{U}$ and its long-lived daughter products-i.e., ${ }^{234} \mathrm{U}$ and ${ }^{230} \mathrm{Th}$ - after death and emergence. The solitary coral Balanophyllia elegans currently lives along the Pacific Coast of North America from southeastern Alaska to central Baja California (Gerrodette, 1979; O'Clair and O'Clair, 1998). This coral also occurs as a fossil in marine-terrace deposits on the Pacific Coast of North America. It is potentially suitable for U-series dating because living specimens incorporate measurable $U$ in isotopic equilibrium with seawater (Stein et al., 1991; Muhs et al., 1994b). TIMS U-series analyses of solitary corals by Stein et al. (1991) did not yield results that were optimistic for high-precision geochronology, as most samples gave evidence of open-system history. However, later alpha-spectrometric U-series analyses suggest that $B$. elegans has potential for dating (Muhs et al., 1994b).

All Balanophyllia specimens were prepared by hand removal of detrital mineral grains and careful scraping of secondary carbonates under magnification, followed by multiple ultrasonic baths in distilled water. The cleaned corals that were analyzed were all well preserved and $95 \%-100 \%$ aragonite, as determined by $\mathrm{X}$-ray diffractometry. After cleaning, sample preparation followed methods outlined by Ludwig et al. (1992) and are summarized briefly here. Cleaned corals were dissolved in $\mathrm{HNO}_{3}$, spiked with ${ }^{229} \mathrm{Th},{ }^{233} \mathrm{U}$, and ${ }^{236} \mathrm{U}$ and purified with ion-exchange methods. Purified $\mathrm{U}$ and Th were loaded with colloidal graphite on separate Re filaments; isotopic abundances were determined by thermal-ionization mass spectrometry (TIMS). Ages were calculated by using a half-life of $75381 \mathrm{yr}$ for ${ }^{230} \mathrm{Th}$ and $244600 \mathrm{yr}$ for ${ }^{234} \mathrm{U}$ (Table 1). Cheng et al. (2000) have redetermined the half-life of ${ }^{230} \mathrm{Th}$ to be $75690 \mathrm{yr}$ and the half-life of ${ }^{234} \mathrm{U}$ to be 245250 yr. Recalculation of our U-series data using these new half-lives results in ages that are in agreement, within analytical uncertainty, with the ages reported in Table 1. Duplicate analyses of individual coral samples generally show excellent agreement, within limits of analytical uncertainty.

\section{URANIUM-SERIES AGES OF MARINE- TERRACE CORALS}

\section{U-Series Systematics in Modern Corals}

A previous study, using alpha spectrometry, showed that $\mathrm{U}$ concentrations in living Balanophyllia elegans from California and Oregon are $\sim 3.2 \mathrm{ppm}$, whereas U concentrations in fossils of this species range from $\sim 3.7$ to $5.7 \mathrm{ppm}$ (Muhs et al., 1994b). Muhs et al. (1994b) suggested that secondary U uptake could have occurred after death but before emergence from seawater, in which case the 
MUHS et al.

TABLE 1. U AND Th CONCENTRATIONS, ISOTOPIC RATIOS, AND AGES OF CORALS FROM CALIFORNIA AND BAJA CALIFORNIA

\begin{tabular}{|c|c|c|c|c|c|c|c|c|c|c|c|c|c|}
\hline $\begin{array}{l}\text { Locality and } \\
\text { sample } \\
\text { number }\end{array}$ & $\begin{array}{l}\text { Terrace and } \\
\text { LACMIP } \\
\text { locality }\end{array}$ & $\underset{(\mathrm{ppm})}{U}$ & Error & $\begin{array}{l}\text { 232Th } \\
(\mathrm{ppm})\end{array}$ & $\begin{array}{c}{ }^{234} \mathrm{U} / 238 \mathrm{U} \\
\mathrm{AR}\end{array}$ & Error & $\begin{array}{c}{ }^{230} \mathrm{Th} /{ }^{238} \mathrm{U} \\
\mathrm{AR}\end{array}$ & Error & $\begin{array}{c}{ }^{230} \mathrm{Th} / 232 \mathrm{Th} \\
\mathrm{AR}\end{array}$ & $\begin{array}{c}{ }^{230} \mathrm{Th} / 238 \mathrm{U} \\
\text { age } \\
\text { (ka) }\end{array}$ & Error & $\begin{array}{c}{ }^{234} \mathrm{U} / 238 \mathrm{U} \\
\text { initial } \\
\mathrm{AR}\end{array}$ & Error \\
\hline \multicolumn{14}{|c|}{ Cayucos, California-Cayucos terrace } \\
\hline Cay-10731-A & 10731 & 4.35 & 0.11 & 0.0153 & 1.1343 & 0.0016 & 0.7614 & 0.0031 & 656 & 117.1 & 0.9 & 1.1872 & 0.0021 \\
\hline Cay-10731-A dup & 10731 & 4.17 & 0.11 & 0.0207 & 1.1387 & 0.0017 & 0.7654 & 0.0029 & 467 & 117.3 & 0.8 & 1.1934 & 0.0022 \\
\hline Cay-10731-B & 10731 & 4.85 & 0.12 & 0.0178 & 1.1313 & 0.0018 & 0.7324 & 0.0049 & 605 & 110.1 & 1.3 & 1.1794 & 0.0024 \\
\hline Cay-10731-C & 10731 & 3.88 & 0.11 & 0.0194 & 1.1240 & 0.0017 & 0.7212 & 0.0022 & 437 & 108.7 & 0.6 & 1.1687 & 0.0022 \\
\hline Cay-10731-E & 10731 & 4.56 & 0.11 & 0.0272 & 1.1232 & 0.0015 & 0.7237 & 0.0019 & 368 & 109.4 & 0.6 & 1.1680 & 0.0019 \\
\hline Cay-10731-F & 10731 & 4.07 & 0.11 & 0.0304 & 1.1254 & 0.0016 & 0.7505 & 0.0025 & 305 & 116.0 & 0.8 & 1.1742 & 0.0021 \\
\hline Cay-10731-G & 10731 & 4.83 & 0.11 & 0.0209 & 1.1164 & 0.0019 & 0.7434 & 0.0028 & 521 & 115.9 & 0.9 & 1.1617 & 0.0025 \\
\hline Cay-10731-H & 10731 & 4.59 & 0.11 & 0.0252 & 1.1317 & 0.0058 & 0.7815 & 0.0050 & 432 & 123.3 & 1.9 & 1.1867 & 0.0076 \\
\hline GK-89-07-A & 11923 & 5.06 & 0.12 & 0.0452 & 1.1294 & 0.0019 & 0.8037 & 0.0055 & 273 & 130.3 & 1.7 & 1.1872 & 0.0027 \\
\hline GK-89-07-B & 11923 & 4.82 & 0.11 & 0.0504 & 1.1202 & 0.0019 & 0.8289 & 0.0038 & 241 & 140.8 & 1.4 & 1.1791 & 0.0027 \\
\hline GK-89-07-C & 11923 & 4.29 & 0.11 & 0.0201 & 1.1370 & 0.0022 & 0.7918 & 0.0023 & 514 & 125.0 & 0.8 & 1.1953 & 0.0028 \\
\hline GK-89-07-D & 11923 & 4.98 & 0.11 & 0.0449 & 1.1295 & 0.0023 & 0.7911 & 0.0026 & 266 & 126.5 & 0.9 & 1.1854 & 0.0030 \\
\hline GK-89-07-E & 11923 & 3.69 & 0.11 & 0.2029 & 1.1838 & 0.0032 & 0.8712 & 0.0072 & 48 & 137.1 & 2.3 & 1.2710 & 0.0044 \\
\hline GK-89-07-F & 11923 & 4.60 & 0.11 & 0.0375 & 1.1398 & 0.0020 & 0.7923 & 0.0039 & 295 & 124.5 & 1.2 & 1.1990 & 0.0026 \\
\hline GK-89-07-G & 11923 & 4.70 & 0.11 & 0.0163 & 1.1366 & 0.0027 & 0.8086 & 0.0033 & 709 & 130.0 & 1.2 & 1.1975 & 0.0036 \\
\hline GK-89-07-H & 11923 & 4.79 & 0.12 & 0.0120 & 1.1306 & 0.0018 & 0.7669 & 0.0022 & 932 & 119.4 & 0.7 & 1.1832 & 0.0024 \\
\hline GK-89-07-I & 11923 & 4.14 & 0.11 & 0.0187 & 1.1299 & 0.0017 & 0.7837 & 0.0024 & 525 & 124.3 & 0.8 & 1.1847 & 0.0022 \\
\hline GK-89-7 & 11923 & 4.30 & 0.11 & 0.0332 & 1.1425 & 0.0020 & 0.7914 & 0.0025 & 312 & 123.6 & 0.8 & 1.2023 & 0.0026 \\
\hline GK-89-06-A & 11922 & 4.68 & 0.23 & 0.0313 & 1.1508 & 0.0091 & 0.8613 & 0.0041 & 390 & 142.9 & 2.9 & 1.2261 & 0.0120 \\
\hline GK-89-06-B & 11922 & 4.57 & 0.11 & 0.0488 & 1.1231 & 0.0021 & 0.7976 & 0.0034 & 227 & 130.0 & 1.2 & 1.1780 & 0.0028 \\
\hline GK-89-06-C & 11922 & 4.44 & 0.11 & 0.0393 & 1.1286 & 0.0016 & 0.8218 & 0.0072 & 282 & 136.1 & 2.3 & 1.1892 & 0.0025 \\
\hline \multicolumn{14}{|c|}{ Point Loma, San Diego, California-Bird Rock terrace } \\
\hline GK-93-01-A & 11701 & 4.97 & 0.11 & 0.0918 & 1.1397 & 0.0019 & 0.6398 & 0.0042 & 105 & 87.7 & 0.9 & 1.1792 & 0.0024 \\
\hline GK-93-01-B & 11701 & 4.70 & 0.14 & 0.1112 & 1.1497 & 0.0023 & 0.6878 & 0.0030 & 88 & 96.6 & 0.7 & 1.1968 & 0.0029 \\
\hline GK-93-01-D & 11701 & 4.45 & 0.11 & 0.0563 & 1.1458 & 0.0020 & 0.8067 & 0.0027 & 194 & 127.3 & 0.9 & 1.2091 & 0.0026 \\
\hline \multicolumn{14}{|c|}{ Point Loma, San Diego, California-Nestor terrace } \\
\hline NT-SD-A & 10167 & 5.34 & 0.11 & 0.0293 & 1.1249 & 0.0016 & 0.7468 & 0.0019 & 413 & 115.1 & 0.6 & 1.1731 & 0.0021 \\
\hline NT-SD-B & 10167 & 4.77 & 0.12 & 0.0340 & 1.1359 & 0.0017 & 0.7561 & 0.0035 & 322 & 115.4 & 1.0 & 1.1885 & 0.0023 \\
\hline NT-SD-C & 10167 & 6.96 & 0.11 & 0.0148 & 1.1592 & 0.0021 & 0.7382 & 0.0019 & 1052 & 106.6 & 0.6 & 1.2153 & 0.0026 \\
\hline NT-SD-D & 10167 & 4.87 & 0.11 & 0.0244 & 1.1361 & 0.0023 & 0.8021 & 0.0027 & 486 & 128.2 & 1.0 & 1.1958 & 0.0030 \\
\hline NT-SD-E & 10167 & 6.08 & 0.11 & 0.0605 & 1.1404 & 0.0022 & 0.7490 & 0.0020 & 229 & 112.7 & 0.7 & 1.1932 & 0.0028 \\
\hline NT-SD-F & 10167 & 4.78 & 0.11 & 0.0129 & 1.1364 & 0.0017 & 0.7322 & 0.0018 & 827 & 109.1 & 0.5 & 1.1859 & 0.0022 \\
\hline NT-SD-G & 10167 & 5.56 & 0.11 & 0.0325 & 1.1233 & 0.0014 & 0.7359 & 0.0030 & 382 & 112.6 & 0.8 & 1.1696 & 0.0018 \\
\hline NT-SD-H & 10167 & 3.87 & 0.11 & 0.0181 & 1.1276 & 0.0017 & 0.7916 & 0.0028 & 513 & 127.1 & 0.9 & 1.1830 & 0.0023 \\
\hline NT-SD-I & 10167 & 5.15 & 0.11 & 0.0445 & 1.1464 & 0.0017 & 0.7605 & 0.0040 & 267 & 114.5 & 1.1 & 1.2025 & 0.0023 \\
\hline NT-SD-J & 10167 & 5.80 & 0.11 & 0.0310 & 1.1436 & 0.0017 & 0.6924 & 0.0024 & 393 & 98.5 & 0.6 & 1.1898 & 0.0022 \\
\hline NT-SD-K & 10167 & 4.22 & 0.11 & 0.0315 & 1.1326 & 0.0018 & 0.8650 & 0.0041 & 352 & 149.6 & 1.6 & 1.2026 & 0.0026 \\
\hline NT-SD-L & 10167 & 3.91 & 0.12 & 0.0254 & 1.1307 & 0.0017 & 0.7966 & 0.0030 & 373 & 127.9 & 1.0 & 1.1878 & 0.0023 \\
\hline NT-SD-N & 10167 & 5.47 & 0.11 & 0.0594 & 1.1389 & 0.0022 & 0.7637 & 0.0033 & 214 & 116.8 & 1.0 & 1.1934 & 0.0029 \\
\hline \multicolumn{14}{|c|}{ San Clemente Island, California-Eel Point terrace, north side of Eel Point } \\
\hline SCl-18-A & 10725 & 4.28 & 0.11 & 0.0649 & 1.1078 & 0.0019 & 0.8188 & 0.0029 & 164 & 141.0 & 1.1 & 1.1607 & 0.0027 \\
\hline SCl-18-B & 10725 & 3.83 & 0.11 & 0.0029 & 1.1117 & 0.0026 & 0.7482 & 0.0059 & 2975 & 118.2 & 1.7 & 1.1562 & 0.0034 \\
\hline SCl-18-C & 10725 & 4.35 & 0.11 & 0.0819 & 1.1097 & 0.0029 & 0.8091 & 0.0026 & 131 & 137.2 & 1.2 & 1.1619 & 0.0039 \\
\hline SCl-18-D & 10725 & 3.42 & 0.11 & 0.0066 & 1.1135 & 0.0026 & 0.7554 & 0.0047 & 1196 & 119.9 & 1.4 & 1.1594 & 0.0034 \\
\hline SCl-18-E & 10725 & 4.36 & 0.11 & 0.0022 & 1.1083 & 0.0020 & 0.7505 & 0.0025 & 4582 & 119.6 & 0.8 & 1.1520 & 0.0026 \\
\hline $\mathrm{SCl}-18-\bar{F}$ & 10725 & 3.54 & 0.12 & 0.0070 & 1.1123 & 0.0022 & 0.7580 & 0.0041 & 1159 & 120.9 & 1.3 & 1.1582 & 0.0030 \\
\hline Eel Pt.-A & 10725 & 3.65 & 0.12 & 0.0049 & 1.1085 & 0.0021 & 0.7323 & 0.0028 & 1657 & 114.5 & 0.9 & 1.1500 & 0.0028 \\
\hline Eel Pt.-B & 10725 & 4.29 & 0.11 & 0.0029 & 1.1066 & 0.0025 & 0.7423 & 0.0019 & 3351 & 117.7 & 0.8 & 1.1488 & 0.0033 \\
\hline Eel Pt.-C & 10725 & 3.65 & 0.12 & 0.0018 & 1.1099 & 0.0018 & 0.7458 & 0.0017 & 4484 & 117.9 & 0.6 & 1.1535 & 0.0023 \\
\hline Eel Pt.-D & 10725 & 4.27 & 0.12 & 0.0036 & 1.1078 & 0.0021 & 0.7419 & 0.0035 & 2631 & 117.3 & 1.1 & 1.1503 & 0.0028 \\
\hline Eel Pt.-E & 10725 & 4.15 & 0.11 & 0.0138 & 1.1084 & 0.0014 & 0.7309 & 0.0037 & 669 & 114.2 & 1.0 & 1.1498 & 0.0019 \\
\hline Eel Pt.-G & 10725 & 4.13 & 0.11 & 0.0022 & 1.1109 & 0.0019 & 0.7810 & 0.0070 & 4539 & 128.0 & 2.2 & 1.1594 & 0.0027 \\
\hline Eel Pt.-H & 10725 & 4.17 & 0.12 & 0.0061 & 1.1088 & 0.0026 & 0.8548 & 0.0045 & 1767 & 153.7 & 1.9 & 1.1682 & 0.0036 \\
\hline Eel Pt.-I & 10725 & 3.76 & 0.11 & 0.0059 & 1.1145 & 0.0019 & 0.7487 & 0.0046 & 1456 & 117.8 & 1.3 & 1.1599 & 0.0025 \\
\hline Eel Pt.-J & 10725 & 4.65 & 0.11 & 0.0019 & 1.1110 & 0.0020 & 0.7657 & 0.0038 & 5721 & 123.4 & 1.2 & 1.1575 & 0.0027 \\
\hline
\end{tabular}

U-series ages of B. elegans should still provide a reliable chronology for the marine deposits with which they are associated. To test this hypothesis, we analyzed both livecollected B. elegans from San Nicolas and San Clemente Islands (Fig. 1) and modern, deadcollected specimens from San Nicolas Island. Living Balanophyllia have U concentrations ranging from 2.9 to $3.7 \mathrm{ppm}$ (Fig. 3) and ${ }^{234} \mathrm{U} /{ }^{238} \mathrm{U}$ values that fall within the range of ratios reported for modern seawater (Chen et al., 1986). Apparent ages of the dead-collected specimens from modern beaches on $\mathrm{San} \mathrm{Ni}$ colas Island range from $100 \pm 100 \mathrm{yr}$ to 800 \pm 100 yr. The modern, dead-collected $\mathrm{Bal}$ anophyllia also have ${ }^{234} \mathrm{U} / 238 \mathrm{U}$ values that fall within the range of modern seawater, but have $\mathrm{U}$ concentrations that range from 3.2 to 4.7 ppm (Fig. 3). These data support the earlier suggestion that secondary $U$ uptake occurs in Balanophyllia elegans after death, but that the source of this $U$ is seawater. Similar results have been reported for live-collected and Holocene mollusks, although the concentrations of $\mathrm{U}$ in living mollusks are about two orders of magnitude lower than those in Balanophyllia and other corals (Kaufman et al., 1996). The inference of secondary addition of $U$ from seawater for dead San Nicolas Island corals is supported by detailed analyses of bulk marineterrace sediments on San Nicolas Island that show ${ }^{234} \mathrm{U} /{ }^{238} \mathrm{U}$ values consistently much higher than seawater ratios (Muhs et al., 1989). Because the range of $U$ concentrations in fossil Balanophyllia (Muhs et al., 1994b) differs little from that in modern, dead-collected $\mathrm{Bal}$ - 
TABLE 1. (CONTINUED.)

\begin{tabular}{|c|c|c|c|c|c|c|c|c|c|c|c|c|c|}
\hline $\begin{array}{l}\text { Locality and } \\
\text { sample } \\
\text { number }\end{array}$ & $\begin{array}{l}\text { Terrace and } \\
\text { LACMIP } \\
\text { locality }\end{array}$ & $\underset{(\mathrm{ppm})}{U}$ & Error & $\begin{array}{l}{ }^{232} \mathrm{Th} \\
(\mathrm{ppm})\end{array}$ & $\begin{array}{c}{ }^{234} \mathrm{U} /{ }^{238} \mathrm{U} \\
\mathrm{AR}\end{array}$ & Error & $\begin{array}{c}{ }^{230} \mathrm{Th} / 238 \mathrm{U} \\
\mathrm{AR}\end{array}$ & Error & $\begin{array}{c}{ }^{230} \mathrm{Th} /{ }^{232} \mathrm{Th} \\
\mathrm{AR}\end{array}$ & $\begin{array}{c}{ }^{230} \mathrm{Th} / 238 \mathrm{U} \\
\text { age } \\
\text { (ka) }\end{array}$ & Error & $\begin{array}{c}{ }^{234} \mathrm{U} / 238 \mathrm{U} \\
\text { initial } \\
\text { AR }\end{array}$ & Error \\
\hline \multicolumn{14}{|c|}{ San Clemente Island, California-Eel Point terrace, south side of Eel Point } \\
\hline GK-99-10-B & 12007 & 3.46 & 0.11 & 0.0051 & 1.1127 & 0.0019 & 0.7607 & 0.0025 & 1567 & 121.5 & 0.8 & 1.1591 & 0.0025 \\
\hline GK-99-10-B dup & 12007 & 3.46 & 0.13 & 0.0050 & 1.1127 & 0.0021 & 0.7592 & 0.0026 & 1587 & 121.1 & 0.9 & 1.1589 & 0.0028 \\
\hline GK-99-10-C & 12007 & 3.28 & 0.10 & 0.0059 & 1.1175 & 0.0013 & 0.7596 & 0.0023 & 1279 & 120.2 & 0.7 & 1.1652 & 0.0018 \\
\hline GK-99-10-D & 12007 & 4.35 & 0.11 & 0.0076 & 1.1121 & 0.0019 & 0.7540 & 0.0019 & 1304 & 119.8 & 0.7 & 1.1574 & 0.0025 \\
\hline GK-99-10-E & 12007 & 3.65 & 0.11 & 0.0039 & 1.1122 & 0.0019 & 0.7614 & 0.0016 & 2167 & 121.9 & 0.6 & 1.1584 & 0.0025 \\
\hline GK-99-10-F & 12007 & 4.03 & 0.11 & 0.0117 & 1.1126 & 0.0021 & 0.7520 & 0.0021 & 785 & 119.1 & 0.7 & 1.1577 & 0.0028 \\
\hline GK-99-10-G & 12007 & 3.66 & 0.11 & 0.0073 & 1.1132 & 0.0016 & 0.7522 & 0.0022 & 1142 & 119.0 & 0.7 & 1.1586 & 0.0021 \\
\hline GK-99-10-H & 12007 & 3.49 & 0.11 & 0.0051 & 1.1169 & 0.0018 & 0.7648 & 0.0029 & 1596 & 121.8 & 0.9 & 1.1651 & 0.0024 \\
\hline GK-99-10-I & 12007 & 3.18 & 0.11 & 0.0061 & 1.1225 & 0.0019 & 0.7689 & 0.0038 & 1211 & 121.7 & 1.2 & 1.1729 & 0.0025 \\
\hline GK-99-10-J & 12007 & 3.89 & 0.11 & 0.0147 & 1.1151 & 0.0018 & 0.7610 & 0.0039 & 612 & 121.1 & 1.2 & 1.1622 & 0.0024 \\
\hline GK-99-10-K & 12007 & 3.71 & 0.11 & 0.0096 & 1.1224 & 0.0016 & 0.7643 & 0.0024 & 900 & 120.4 & 0.8 & 1.1722 & 0.0021 \\
\hline GK-99-10-L & 12007 & 3.92 & 0.11 & 0.0063 & 1.1154 & 0.0017 & 0.7703 & 0.0042 & 1458 & 123.7 & 1.3 & 1.1639 & 0.0023 \\
\hline GK-99-10-M & 12007 & 3.87 & 0.13 & 0.0043 & 1.1126 & 0.0017 & 0.7608 & 0.0020 & 2075 & 121.6 & 0.7 & 1.1590 & 0.0022 \\
\hline GK-99-10-O & 12007 & 4.09 & 0.12 & 0.0220 & 1.1203 & 0.0018 & 0.7785 & 0.0034 & 441 & 125.0 & 1.1 & 1.1715 & 0.0024 \\
\hline \multicolumn{14}{|c|}{ Punta Banda, Baja California-Lighthouse terrace } \\
\hline PB-Lth-01-A & 10619 & 3.69 & 0.12 & 0.0053 & 1.1266 & 0.0027 & 0.6022 & 0.0015 & 1280 & 81.7 & 0.4 & 1.1595 & 0.0033 \\
\hline PB-Lth-01-A dup \#1 & 10619 & 3.68 & 0.12 & 0.0056 & 1.1259 & 0.0019 & 0.6007 & 0.0017 & 1187 & 81.4 & 0.4 & 1.1586 & 0.0023 \\
\hline PB-Lth-01-Aa & 10619 & 3.33 & 0.13 & 0.0071 & 1.1313 & 0.0023 & 0.6100 & 0.0046 & 867 & 82.7 & 0.9 & 1.1659 & 0.0028 \\
\hline PB-Lth-01-B & 10619 & 4.33 & 0.12 & 0.0029 & 1.1219 & 0.0017 & 0.5890 & 0.0021 & 2631 & 79.6 & 0.5 & 1.1528 & 0.0020 \\
\hline PB-Lth-01-C & 10619 & 4.05 & 0.12 & 0.0046 & 1.1201 & 0.0015 & 0.6040 & 0.0024 & 1608 & 82.8 & 0.5 & 1.1519 & 0.0018 \\
\hline PB-Lth-01-D & 10619 & 4.41 & 0.23 & 0.0087 & 1.1200 & 0.0043 & 0.5921 & 0.0024 & 914 & 80.4 & 0.7 & 1.1507 & 0.0051 \\
\hline PB-Lth-01-E & 10619 & 2.78 & 0.11 & 0.0192 & 1.1349 & 0.0024 & 0.6364 & 0.0055 & 280 & 87.6 & 1.2 & 1.1729 & 0.0030 \\
\hline \multirow{2}{*}{\multicolumn{14}{|c|}{ Punta Banda, Baja California-Sea Cave terrace }} \\
\hline & & & & & & & & & & & & & \\
\hline PB-SCT-01-A & 10130 & 3.59 & 0.12 & 0.0042 & 1.1111 & 0.0018 & 0.7555 & 0.0027 & 1952 & 120.4 & 0.9 & 1.1563 & 0.0024 \\
\hline PB-SCT-01-B & 0130 & 4.08 & 0.12 & 0.00 & 1.1103 & & 0.7527 & 0.0027 & 1976 & 119.8 & 0.9 & 1.1549 & 0.0029 \\
\hline PB-SCT-01-C & 10130 & 4.20 & 0.11 & 0.00 & 1.1110 & 0.0016 & 0.7514 & 0.0022 & 263 & 119.3 & 0.7 & 1.1556 & 0.0021 \\
\hline PB-SCT-01-D & 10130 & 3.42 & 0.12 & 0.0072 & 1.1139 & 0.0025 & 0.7623 & 0.0020 & 1104 & 121.7 & 0.8 & 1.1608 & 0.0032 \\
\hline PB-SCT-01-Db & 10130 & 3.61 & 0.13 & 0.0125 & 1.1128 & 0.0022 & 0.7649 & 0.0056 & 673 & 122.7 & 1.7 & 1.1597 & 0.0030 \\
\hline PB-SCT-01-E & 10130 & 3.51 & 0.11 & 0.0054 & 1.1130 & 0.0018 & 0.7651 & 0.0016 & 1513 & 122.8 & 0.6 & 1.1600 & 0.0023 \\
\hline PB-SCT-01-F & 10130 & 4.29 & 0.11 & 0.01 & & 0.0018 & 0.7603 & 0.0044 & 79 & 122.6 & 1.4 & 1.1521 & 0.0024 \\
\hline PB-SCT-01-G & 10130 & 4.09 & 0.11 & 0.0060 & 1.1088 & 0.0022 & 0.7477 & 0.0030 & 1548 & 118.7 & 1.0 & 1.1523 & 0.0029 \\
\hline PB-SCT-01-H & 10130 & 3.91 & 0.13 & 0.0033 & 1.1116 & 0.0030 & 0.7594 & 0.0019 & 2766 & 121.4 & 0.9 & 1.1575 & 0.0039 \\
\hline PB-SCT-01-I & 10130 & 4.09 & 0.12 & 0.0092 & 1.1085 & 0.0016 & 0.7314 & 0.0023 & 984 & 114.3 & 0.7 & 1.1500 & 0.0020 \\
\hline PB-SCT-01-J & 10130 & 3.83 & 0.11 & 0.00 & & 0.0020 & 0.7568 & & 1857 & 121.0 & 0.9 & & 0.0026 \\
\hline PB-SCT-01-K & 10130 & 3.80 & 0.11 & 0.0079 & 1.1094 & 0.0014 & 0.7541 & 0.0033 & 1097 & 120.4 & 1.0 & 1.1539 & 0.0019 \\
\hline PB-SCT-01-L & 10130 & 4.34 & 0.11 & 0.0087 & 1.1081 & 0.0016 & 0.7555 & 0.0023 & 1147 & 121.1 & 0.7 & 1.1524 & 0.0021 \\
\hline PB-SCT-01-M & 10130 & 3.67 & 0.11 & 0.0071 & 1.1122 & 0.0013 & 0.7669 & 0.0041 & 1195 & 123.5 & 1.2 & 1.1592 & 0.0018 \\
\hline PB-SCT-01-N & 10130 & 3.98 & 0.11 & 0.0195 & 1.1129 & 0.0023 & 0.7682 & 0.0028 & 477 & 123.7 & 1.0 & 1.1603 & 0.0031 \\
\hline PB-SCT-01-O & 10130 & 3.35 & 0.12 & 0.0328 & 1.1186 & 0.0028 & 0.7842 & 0.0112 & 243 & 127.1 & 3.4 & 1.1700 & 0.0041 \\
\hline \multicolumn{14}{|c|}{ Isla de Guadalupe, Baja California-Discovery Point Formation, SDSNH localities } \\
\hline $\mathrm{Gl}-01-\mathrm{a}$ & 0644 & & 0.12 & 0.0056 & 1.1119 & 0.0019 & 0.7646 & 0.0021 & 1264 & 122.9 & 0.7 & 1.1585 & 0.0025 \\
\hline GI-01-b redo & 0644 & 2.93 & 0.11 & 0.00 & 1.1137 & 0.0021 & 0.7488 & 0.0044 & 35472 & 118 & 1.3 & 1.15 & 0.0028 \\
\hline $\mathrm{Gl}-01-\mathrm{C}$ & 0644 & 3.04 & 0.12 & 0.0048 & 1.1103 & 0.0012 & 0.7624 & 0.0022 & 1462 & 122.6 & 0.7 & 1.1562 & 0.0016 \\
\hline $\mathrm{Gl}-2$ & 0633 & 2.88 & 0.12 & 0.0008 & 1.1128 & 0.0018 & 0.7802 & 0.0042 & 8924 & 127.3 & 1.3 & 1.1618 & 0.0024 \\
\hline GI-03-a & 2465 & 2.83 & 0.11 & 0.0078 & 1.1128 & 0.0017 & 0.7650 & 0.0019 & 845 & 122.8 & 0.7 & 1.1597 & 0.0022 \\
\hline GI-03-b & 2465 & 2.77 & 0.11 & 0.0048 & 1.1151 & 0.0017 & 0.7693 & 0.0042 & 1343 & 123.5 & 1.3 & 1.1633 & 0.0023 \\
\hline & & 2.90 & 0.12 & & & 0.0020 & 0.7691 & 0.0024 & 23417 & 122.2 & 0.8 & 1.1704 & 0.0027 \\
\hline \multicolumn{14}{|c|}{ Cabo Pulmo, Baja California Sur-Unnamed terrace at $+6 \mathrm{~m}$ above sea level } \\
\hline Baja-2 & 11739 & 2.75 & 0.11 & 0.0073 & 1.1163 & 0.0020 & 0.7821 & 0.0034 & 890 & 127.0 & 1.1 & 1.1667 & 0.0027 \\
\hline Ваја-2a & 11739 & 2.78 & 0.12 & 0.09 & 1.1183 & 0.0025 & 0.7598 & 0.0056 & 71 & 120.1 & 1.7 & 1.1662 & 0.0033 \\
\hline Ваја-5 & 11739 & 2.83 & 0.12 & 0.08 & 1.1274 & 0.0018 & 0.8304 & 0.0034 & 95 & 139.3 & 1.2 & 1.189 & 0.0025 \\
\hline
\end{tabular}

Note: Ages (and their initial U isotope ratios) in bold type have the highest reliability. AR—activity ratio, dup—duplicate, SDSNH—San Diego Society of Natural History.

anophyllia, we conclude that this species still has the potential for accurate age determination of marine-terrace deposits.

As with hermatypic colonial corals from the tropics, the best criterion for determining closedsystem conditions during the postemergence history of a fossil is concordance between ${ }^{230} \mathrm{Th} /{ }^{234} \mathrm{U}$ and ${ }^{231} \mathrm{~Pa} /{ }^{235} \mathrm{U}$ ages. We did not determine ${ }^{231} \mathrm{~Pa} / 235 \mathrm{U}$ ages for our samples. However, a second criterion for closed-system history is whether the calculated initial ${ }^{234} \mathrm{U} /{ }^{238} \mathrm{U}$ value is within the range of this ratio in modern seawater. Edwards et al. (1997) showed that corals with calculated initial ${ }^{234} \mathrm{U} / 238 \mathrm{U}$ values as high as 1.166 showed concordance between ${ }^{230} \mathrm{Th} /{ }^{234} \mathrm{U}$ and ${ }^{231} \mathrm{~Pa} /{ }^{235} \mathrm{U}$ ages. In this study, we consider as "reliable" any corals with initial ${ }^{234} \mathrm{U} /{ }^{238} \mathrm{U}$ values from 1.142 (the lowest ratio measured in living Balanophyllia elegans) to 1.159 (following Stirling et al., 1998).

\section{Cayucos Area, Central California}

The geomorphically well expressed low terrace in the Cayucos area of San Luis Obispo County, California, has long been the focus of study, both for the timing of high sea level and invertebrate paleontology (Valentine, 1958; Veeh and Valentine, 1967; Stein et al., 1991; Muhs et al., 1994b). The terrace is extensive along the central California coast in this area and is easily mapped (Fig. 4). The Cayucos terrace has a shoreline angle elevation of $\sim 7-8 \mathrm{~m}$, and platform exposures in the modern sea cliff are as high as $5 \mathrm{~m}$. The marine deposits on this platform consist of a lag of boulders overlain by fossiliferous sands, cemented in some places into a coquina. Corals were abundant at four localities that we stud- 


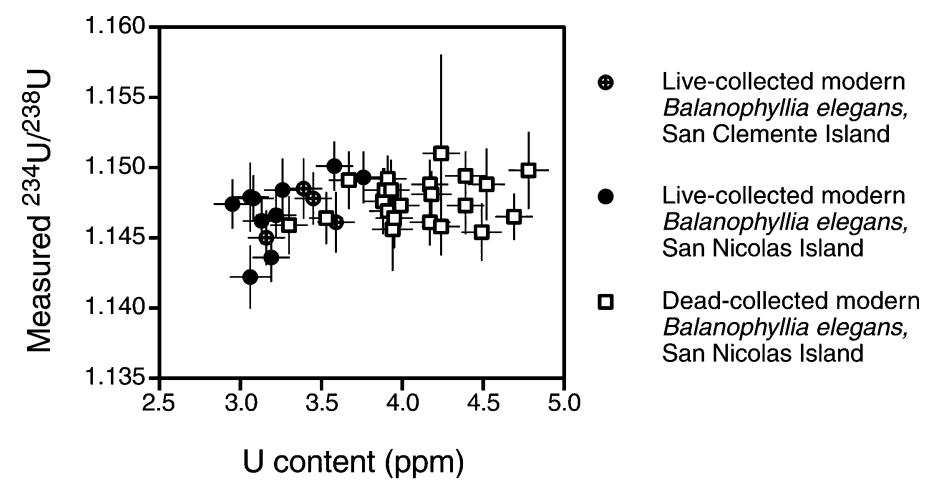

Figure 3. $U$ concentrations and measured ${ }^{234} U / 238 U$ values in modern, live-collected and modern, dead-collected specimens of the solitary coral Balanophyllia elegans from San Nicolas Island and San Clemente Island, California.
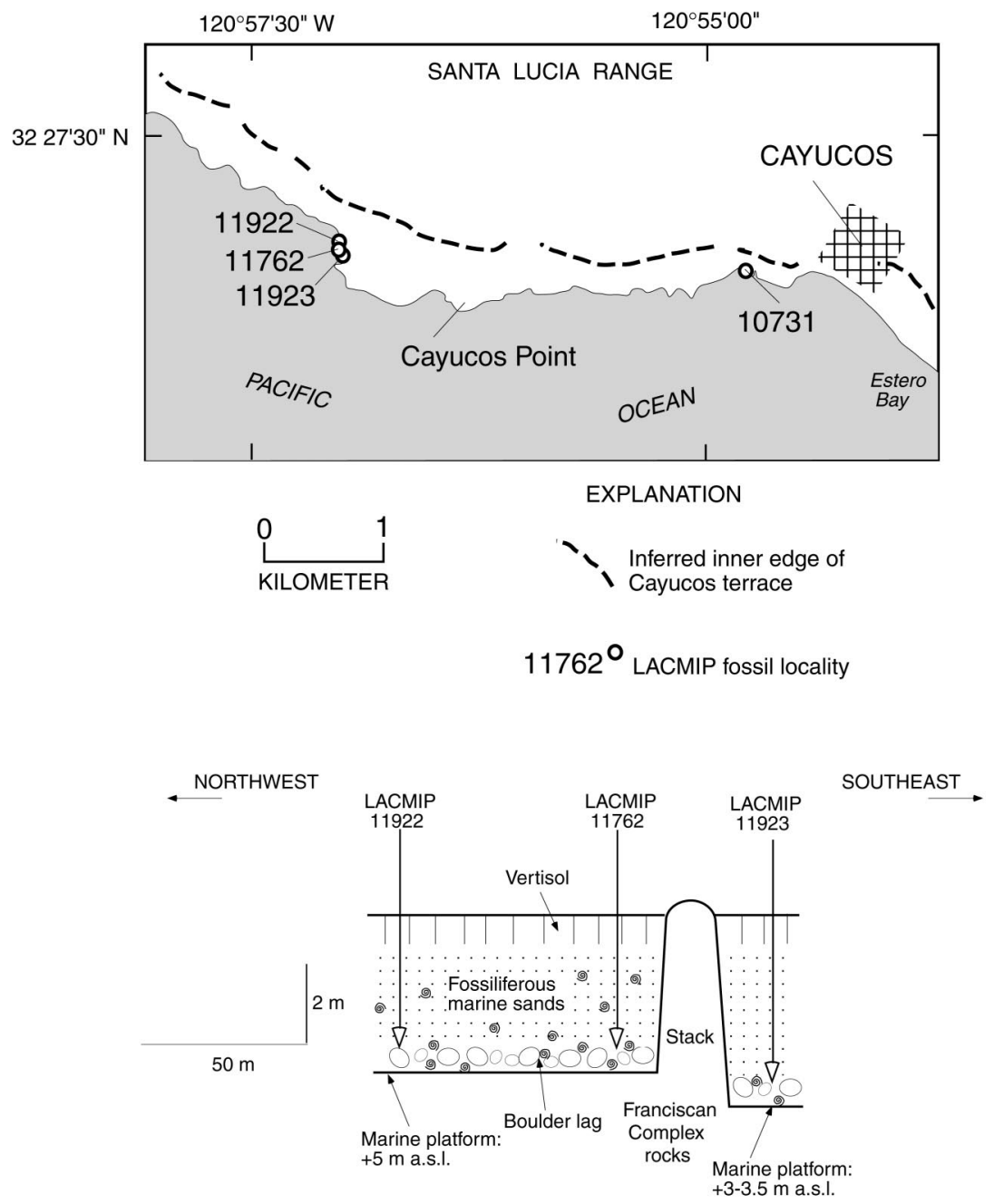

Figure 4. Map showing inferred inner edge of the Cayucos terrace (mapped by the authors), fossil localities, and stratigraphy of fossil localities exposed in sea cliff in the Cayucos area, California. ied (Fig. 4; LACMIP [Los Angeles County Museum, Invertebrate Paleontology] localities 10731, 11762, 11922, 11923).

Previous TIMS U-series analyses of corals from the Cayucos terrace showed that all samples have been affected by open-system conditions, on the basis of initial ${ }^{234} \mathrm{U} /{ }^{238} \mathrm{U}$ values that are much higher than the ratio in modern seawater (Stein et al., 1991). All of these samples came from, or near, our LACMIP location 10731. The apparent ages, with one exception (ca. $101 \mathrm{ka}$ ), ranged from 125 to $113 \mathrm{ka}$, and the initial ${ }^{234} \mathrm{U} /{ }^{238} \mathrm{U}$ values ranged from 1.161 (101 ka sample) to 1.201 (ca. $114 \mathrm{ka}$ sample) (Stein et al., 1991). Our analyses of corals from this locality yielded similar results. The $\mathrm{U}$ contents were within the range of modern, dead-collected corals shown in Figure 3, and the ${ }^{230} \mathrm{Th} /{ }^{232} \mathrm{Th}$ values were high, indicating little or no inherited ${ }^{230} \mathrm{Th}$. Two samples gave apparent ages of ca. 109 ka (also the lowest initial ${ }^{234} \mathrm{U} / 238 \mathrm{U}$ value, 1.168 ), and the rest gave a range of apparent ages from ca. 123 to $116 \mathrm{ka}$ and initial ${ }^{234} \mathrm{U} /{ }^{238} \mathrm{U}$ values of $1.174-$ 1.193. At localities west of Cayucos, and northwest of Cayucos Point, the apparent ages were ca. 143-119 ka, and all samples showed high initial ${ }^{234} \mathrm{U} /{ }^{238} \mathrm{U}$ values.

Anomalously high initial ${ }^{234} U /{ }^{238} U$ values are commonly reported in fossil corals. Gallup et al. (1994) presented a model of continuous, postemergence addition of both ${ }^{230} \mathrm{Th}$ and ${ }^{234} \mathrm{U}$ to Barbados corals that explains the higher initial ${ }^{234} U /{ }^{238} U$ values and a tendency for such corals to show ages older than those with acceptable ${ }^{234} \mathrm{U} / 238 \mathrm{U}$ values from the same deposit. Stirling et al. (1998) concluded that the same processes of nuclide additions have been operating on last interglacial corals in Western Australia. Gallup et al. (1994) estimated the degree of age bias in samples on the basis of trends observed in corals on Barbados. For example, if a fossil coral begins with a ${ }^{234} U /{ }^{238} U$ value of 1.149 and shows a present ${ }^{234} \mathrm{U} /{ }^{238} \mathrm{U}$ value of 1.153, Gallup et al. (1994) estimated an age bias (to an older age) of $\sim 1000 \mathrm{yr}$. In both the Stein et al. (1991) Cayucos data set and our own, the least-biased samples would therefore be those that have apparent ages of younger than ca. $110 \mathrm{ka}$. By using the model of Gallup et al. (1994), the ages of our two youngest samples would be ca. $104 \mathrm{ka}$. These ages agree reasonably well with the estimated age of the Ventnor terrace on Barbados, on the basis of both alpha-spectrometric U-series dating (Ku, 1968; Mesolella et al., 1969; Ku et al., 1990) and more recent TIMS U-series dating (Gallup et al., 1994; Edwards et al., 1997). The ages also correspond to substage $5 \mathrm{c}$ of the deep-sea oxygen isotope record (Martinson et 
al., 1987). If the same model were used, other corals from Cayucos would likely be biased by greater amounts, on the order of 10-30 k.y. Some of these corals could have true ages of ca. 108-102 ka, but others (mostly from the localities northwest of Cayucos Point) could have true ages of ca. 133-110 ka, and many others' true ages could be ca. 126-114 ka. Although we think it is premature to use the Gallup et al. (1994) model as a method for precise correction of corals that have been affected by open-system conditions, we think, as did Stirling et al. (1998), that it is a reasonable first approximation for the degree of age bias. If this opinion is correct, then our data and those of Stein et al. (1991) suggest that corals from Cayucos represent two distinct sea-level highstands that are recorded on Barbados as separate terraces: the ca. $105 \mathrm{ka}$ Ventnor terrace (formed during deep-sea substage 5c) and the ca. 120 ka Rendezvous Hill terrace (formed during deep-sea substage $5 \mathrm{e}$ ). There is no significant difference in physical appearance or stratigraphic position of the corals of $120 \mathrm{ka}$ age and those of $105 \mathrm{ka}$ age, suggesting that the reworking process mixed the corals of the two ages efficiently.

\section{Point Loma, San Diego, California}

Two low marine terraces are present along the west side of Point Loma near San Diego (Fig. 5). The shoreline angle of the lower Bird Rock terrace lies at an elevation of $\sim 8-9 \mathrm{~m}$ and that of the higher Nestor terrace lies at an elevation of $\sim 23-24 \mathrm{~m}$ at the south end of the peninsula (Kern, 1977; Kern and Rockwell, 1992). Both are veneered with a thick cover (up to $\sim 15 \mathrm{~m}$ on the Bird Rock terrace) of nonmarine sediments and paleosols developed in these deposits (Fig. 5). On the basis of previous alpha-spectrometric U-series analyses, the Nestor terrace is thought to date to the ca. 120 ka sea-level highstand, and the Bird Rock terrace is thought to date to the ca. 80 ka sealevel highstand (Ku and Kern, 1974; Muhs et al., 1994b). By using TIMS U-series analyses, Stein et al. (1991) reported ages of ca. 145$133 \mathrm{ka}$ for four corals from the Nestor terrace and an age of ca. $97 \mathrm{ka}$ for a single coral from the Bird Rock terrace, all with high initial ${ }^{234} \mathrm{U} /{ }^{238} \mathrm{U}$ values.

Our results also showed that all corals from the Nestor and Bird Rock terraces have been subject to open-system conditions, in agreement with Stein et al. (1991). Apparent ages for the Nestor terrace range from ca. 150 to $98 \mathrm{ka}$ and those from the Bird Rock terrace range from 127 to $88 \mathrm{ka}$. Applying the Gallup et al. (1994) model to the Nestor terrace corals results in two specimens having possible ages of 90-88 ka, seven having possible ages of 109-100 ka, and four having possible ages of 136-116 ka. On the Bird Rock terrace, two corals could have ages of $85-80 \mathrm{ka}$, and one could have an age of ca. $112 \mathrm{ka}$. The two youngest corals from the Nestor terrace (uncorrected ages of ca. 98 and $107 \mathrm{ka}$ ) have exceptionally high $\mathrm{U}$ contents of 5.8 and $7 \mathrm{ppm}$, respectively. We suspect that these corals, along with another (sample NT-SD-E, with 6.1 ppm $\mathrm{U}$ ) have acquired bulk $\mathrm{U}$ additions from terrestrial waters well after terrace emergence, which would tend to bias the corals to younger ages. If we do not consider these high-U samples, the range of possible ages of the Nestor terrace corals is similar to the corals in the Cayucos terrace. The Nestor terrace has both a younger (109-100 ka, "corrected") group that could correspond to the same sea-level highstand as the $105 \mathrm{ka}$ Ventnor terrace on Barbados and an older (136-116 ka, "corrected") group that could correspond to the ca. 120 ka Rendezvous Hill terrace on Barbados. As with the two apparent age groups of corals from Cayucos, the two age groups of Nestor terrace corals do not show any differences in appearance. The Bird Rock terrace could correspond to the ca. $80 \mathrm{ka}$ Worthing terrace on Barbados, although it apparently has at least one older, reworked coral.

\section{San Clemente Island, California}

Marine terraces on San Clemente Island are exceptionally well preserved (Fig. 6). As many as 22 marine terraces may exist on this island, and the youngest of these are very well expressed geomorphically on the northern part of the island (Figs. 7 and 8), where they have been mapped by Muhs (1983). At least 12 terraces are found on the northern part of the island and are cut into Tertiary volcanic rocks, mainly andesite. Marine-terrace deposits are thin, usually less than $1 \mathrm{~m}$ thick, and are only rarely fossiliferous. The second terrace is one of the broadest and geomorphically best expressed landforms on the island (Fig. 6). It was informally designated the "Eel Point terrace" by Muhs and Szabo (1982), Muhs (1983), and Muhs et al. (1994b). When first studied by Muhs (1983), two surfaces were included in what was mapped as the "Eel Point terrace": a narrow, inner (landward) surface that was reported to have a shoreline angle elevation of 30-32 $\mathrm{m}$ and a broader, outer (seaward) surface that has an elevation of $\sim 21$ $\mathrm{m}$ at its inner edge and $\sim 8 \mathrm{~m}$ at its outer edge at Eel Point. Muhs (1983) interpreted the inner surface to be either a storm bench or simply the inner, higher-gradient part of a single terrace that extended seaward all the way to Eel Point (cf. studies of modern shore platforms by Bradley and Griggs, 1976). Pedologic studies indicated little or no difference in degree of soil development on the $30-32 \mathrm{~m}$ and 21 $\mathrm{m}$ surfaces, but soils on the next higher terrace (inner edge at $45-50 \mathrm{~m}$ ) are significantly better developed (Muhs, 1982). Later studies by Kennedy et al. (1995) suggested that the surface whose inner edge is at $30-32 \mathrm{~m}$ is a separate terrace, distinct from the broader, seaward part of the "Eel Point terrace" whose inner edge elevation is $\sim 21 \mathrm{~m}$. Thus, the 30 $32 \mathrm{~m}$ surface may have formed during a relatively high sea stand that occurred before the formation of the $\sim 21 \mathrm{~m}$ surface. In the present study, we mapped the two surfaces separately (Figs. 7 and 8); the inner (30-32 m) surface is referred to as terrace $2 \mathrm{a}$, and the outer $(21 \mathrm{~m})$ surface is referred to as terrace $2 \mathrm{~b}$. The term "Eel Point terrace" now refers strictly to what is mapped as terrace $2 \mathrm{~b}$ in Figures 7 and 8.

The Eel Point terrace has one of the few fossil-bearing localities on the island, at Eel Point itself (Figs. 7 and 8). By using alpha spectrometric U-series methods, Muhs and Szabo (1982) dated the hydrocoral Stylaster californicus from Eel Point to $127000 \pm$

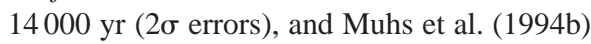
dated a collection of Balanophyllia elegans corals to $111000 \pm 6000 \mathrm{yr}$. Specimens of $B$. elegans were re-collected from exposures on both the north and south sides of Eel Point (Fig. 7) and analyzed individually in the present study.

Corals from the Eel Point terrace on San Clemente Island showed much more evidence for closed-system histories than did corals from either Cayucos or Point Loma (Table 1). All San Clemente Island corals have U contents of 3.4-4.6 ppm, similar to the range for modern, dead-collected corals shown in Figure 3. In addition, with two exceptions (samples SCI-18-A and SCI-18-C), corals from San Clemente Island showed very high ${ }^{230} \mathrm{Th} /{ }^{232} \mathrm{Th}$ values, indicating little or no inherited ${ }^{230} \mathrm{Th}$. Of 29 corals analyzed, 19 had initial ${ }^{234} \mathrm{U} /{ }^{238} \mathrm{U}$ values that ranged from 1.149 to 1.159 , which we consider to be indicative of closed-system histories. At worst, according to the model of Gallup et al. (1994), the samples with the highest initial ${ }^{234} U /{ }^{238} U$ values in this "acceptable" group could be biased to older ages by only $\sim 2500$ yr. Apparent ages of corals in this latter group range from ca. 128 to $114 \mathrm{ka}$, supporting a correlation to the Rendezvous Hill terrace of Barbados.

Two corals from San Clemente Island (samples SCI-18-A and SCI-18-C) have 

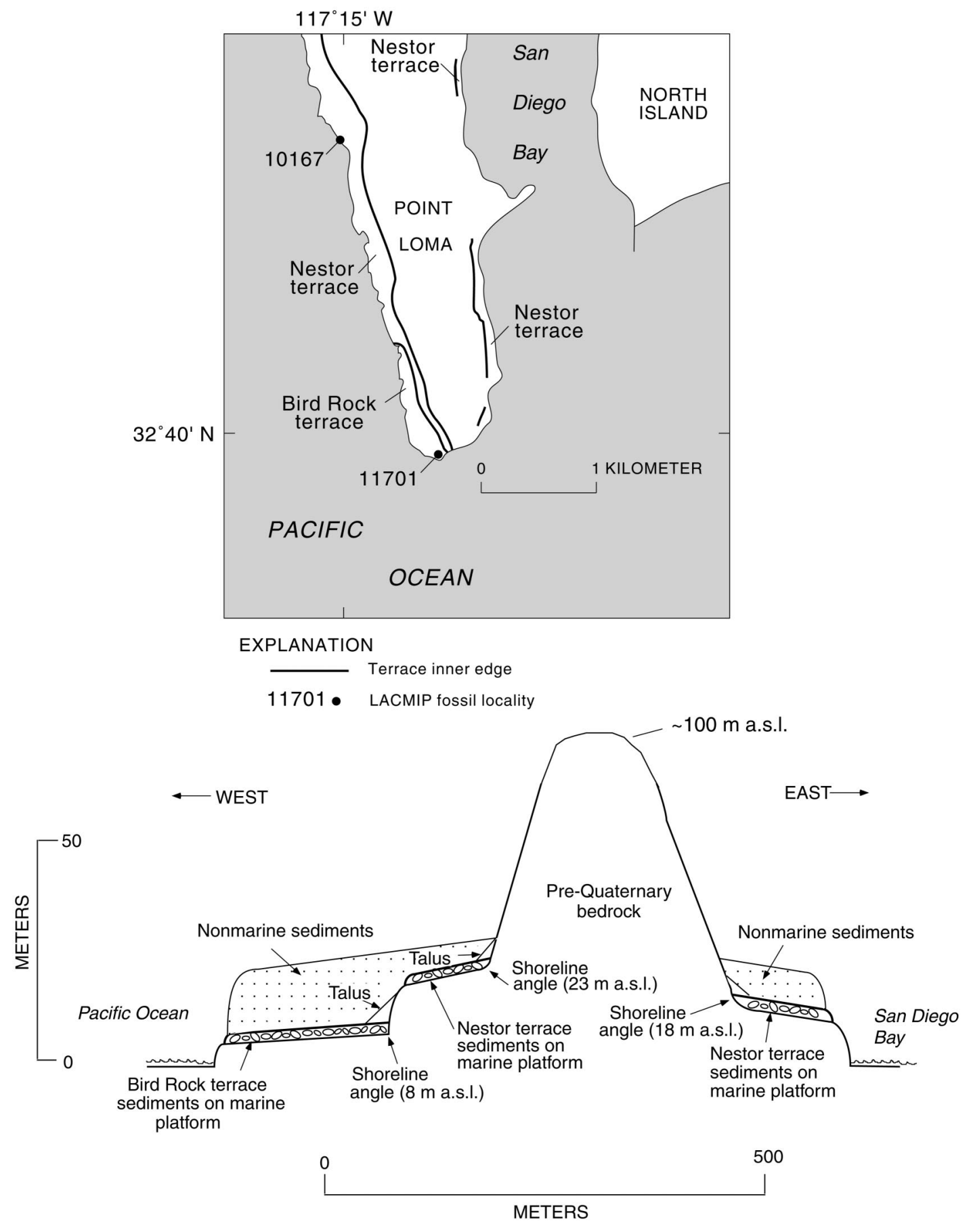

Figure 5. Map showing inferred inner edge of the Nestor and Bird Rock terraces on Point Loma (from Kern, 1977), fossil localities, and cross section of terraces at the south end of Point Loma (stratigraphy by the authors; shoreline angle elevations measured by Kern, 1977).

ages and isotopic ratios that are more difficult to interpret. These two corals have relatively low $(<200){ }^{230} \mathrm{Th} /{ }^{232} \mathrm{Th}$ values, somewhat high (1.161-1.162) initial ${ }^{234} \mathrm{U} /{ }^{238} \mathrm{U}$ values, and significantly older (ca. 141 and ca. $137 \mathrm{ka})$ apparent ages. The lower ${ }^{230} \mathrm{Th} /{ }^{232} \mathrm{Th}$ values suggest some inherited ${ }^{230} \mathrm{Th}$ (due to contaminating minerals), which would tend to bias the results to older ages, as would the higher initial ${ }^{234} \mathrm{U} /{ }^{238} \mathrm{U}$ values. Although we cannot make precise corrections without knowing the ${ }^{230} \mathrm{Th} /{ }^{232} \mathrm{Th}$ value of the contaminating, noncarbonate material, we suspect that these two corals may be biased to older ages by at least several thousand years.

\section{Punta Banda, Northern Baja California}

Twelve marine terraces, well expressed geomorphically, as well as higher undifferentiated terraces, are present on Punta Banda in northern Baja California, just south of Ensenada, Mexico (Fig. 9). Because of faulting of the peninsula, the elevation of the shoreline angle 


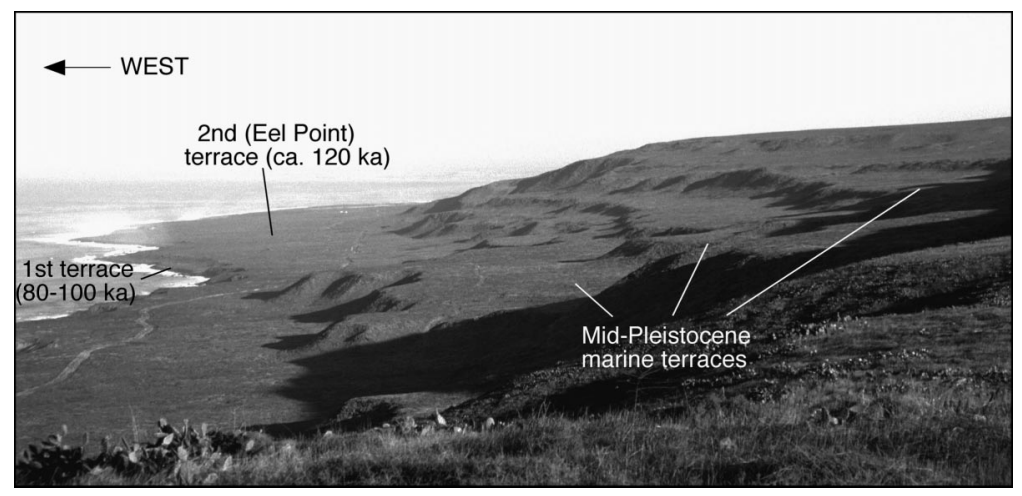

Figure 6. View of marine terraces on the west coast of San Clemente Island, looking northward. Photograph by the authors.

of the first or lowest terrace (Lighthouse terrace) varies from 15 to $18 \mathrm{~m}$, and that of the third terrace (Sea Cave terrace) varies from 34 to $40 \mathrm{~m}$ (Rockwell et al., 1989). Fossiliferous sediments on both terraces (Fig. 9) yielded Balanophyllia elegans. Sediments on an intermediate terrace (elevation, $22 \mathrm{~m}$ ) near the western tip of Punta Banda are unfossiliferous. Rockwell et al. (1989) and Muhs et al. (1994b) reported alpha-spectrometric U-series ages of ca. $80 \mathrm{ka}$ for bulk coral samples (multiple individuals) from the Lighthouse terrace and ages of ca. $120 \mathrm{ka}$ for bulk coral samples from the Sea Cave terrace.

TIMS U-series analyses of Balanophyllia elegans from the Punta Banda terraces, as with those on San Clemente Island, mostly showed evidence of probable closed-system history and therefore have reliable ages (Table 1). For both the Sea Cave and Lighthouse terraces, concentrations of $U$ are within the range of modern, dead-collected solitary corals; ${ }^{230} \mathrm{Th} /{ }^{232} \mathrm{Th}$ values are high, indicating no inherited ${ }^{230} \mathrm{Th}$ daughter species; and 18 of 24 samples have initial ${ }^{234} \mathrm{U} / 238 \mathrm{U}$ values that are 1.159 or lower. With one exception (ca. 114 $\mathrm{ka}$ ), the ages of closed-system corals from the Sea Cave terrace have a narrow range of ca. 123 to ca. $119 \mathrm{ka}$. The overall range of Sea Cave terrace ages is very similar to that of the Eel Point terrace on San Clemente Island. Six Lighthouse terrace corals with acceptable initial ${ }^{234} \mathrm{U} /{ }^{238} \mathrm{U}$ values also have a narrow range of ages, from ca. 83 to ca. $80 \mathrm{ka}$.

\section{Isla de Guadalupe and Cabo Pulmo, Baja California}

Although the focus of our study has been on U-series dating of solitary, ahermatypic corals, some emergent marine deposits in peninsular Baja California well south of Punta Banda contain colonial hermatypic forms, such as Pocillopora and Porites. Muhs et al. (1994b) reported alpha-spectrometric U-series ages of colonial corals from Isla de Guadalupe, to the west of Baja California, and from Cabo Pulmo, on the east coast of Baja California Sur (Figs. 1, 10, 11). In the present study, we redated these corals by using higherprecision TIMS methods.

Isla de Guadalupe is an alkalic seamount on a fossil ridge crest $\sim 330 \mathrm{~km}$ west of Baja California. In places, the island has a fossiliferous Pleistocene marine deposit (called the Discovery Point Formation by Lindberg et al., 1980) within a few meters of present sea level (Fig. 10). The fossiliferous deposit is predominantly conglomerate, but unlike coastal California usually not present. Elevations of the deposit range from near sea level to as high as $6 \mathrm{~m}$ above sea level (Lindberg et al., 1980). In southernmost Baja California Sur, Squires (1959) and Ortlieb (1987) described spatially limited outcrops of a coral-bearing marine conglomerate resting on a granitic platform near Cabo Pulmo (Fig. 11). Ortlieb (1987) inferred a shoreline angle elevation of $\sim 6 \mathrm{~m}$ for the terrace platform at this locality, and new measurements made by us confirm this. Species of the colonial corals Porites and Pocillopora are currently living subtidally offshore Cabo Pulmo, but do not live as far north as Isla de Guadalupe. However, the Discovery Point Formation contains well-preserved specimens of what has been identified as a new species, Pocillopora guadalupensis (Durham, 1980).

Pocillopora from the Discovery Point Formation have $U$ contents of 2.8-3.0 ppm, which is typical of both modern and fossil specimens of Pocillopora (Muhs and Szabo, 1994; Szabo et al., 1994; Muhs et al., 2002). All samples have very high ${ }^{230} \mathrm{Th} /{ }^{232} \mathrm{Th}$ values, indicating no inherited daughter species. All and northern Baja California, a platform is three fragments analyzed from specimen GI-1 have acceptable initial ${ }^{234} \mathrm{U} /{ }^{238} \mathrm{U}$ values (ages of ca. $123-118 \mathrm{ka}$ ), as does one fragment from sample GI-3 (age of ca. $123 \mathrm{ka}$ ). Two fragments of GI-1 have ages that are in agreement with each other, but the third is significantly younger than the other two. However, the younger sample (ca. $118 \mathrm{ka}$ ) may be the closest to the true age, because this fragment has an order-of-magnitude-higher ${ }^{230} \mathrm{Th} /{ }^{232} \mathrm{Th}$ value. None of the samples from Cabo Pulmo has acceptable initial ${ }^{234} \mathrm{U} /{ }^{238} \mathrm{U}$ values, but two specimens of sample Baja-2 (Porites) have ratios of 1.1662-1.1667, suggesting a bias toward older ages of perhaps 4000-5000 yr (thus, true ages of ca. 122-115 ka). Baja-5, a Pocillopora, is clearly biased toward a much older age. Although it is not possible to determine precise ages at Cabo Pulmo, the corals there and from the Discovery Point Formation on Isla de Guadalupe almost certainly represent the same sea-level highstand represented by the Eel Point (San Clemente Island), Sea Cave (Punta Banda), and Rendezvous Hill (Barbados) terraces, all of which correlate to the peak of the last interglacial period, i.e., oxygen isotope substage 5e.

\section{DISCUSSION}

Timing of the Last Interglacial Sea-level Highstand on the Pacific Coast of North America

The marine-terrace record of the Pacific Coast of North America can be compared with tectonically rising islands found in the tropics, where there have been numerous TIMS U-series studies. In this comparison, we refer only to ages that were measured in fossils that showed closed-system conditions, according to the criteria already discussed. On slowly rising Barbados, Hamelin et al. (1991) reported a range of ages for the last interglacial Rendezvous Hill terrace of ca. 133-113 ka, which overlaps the range of 130-117 ka reported by Gallup et al. (1994). Edwards et al. (1987, 1997) reported a more restricted range of ages from 129 to $122 \mathrm{ka}$. On the rapidly uplifting Huon Peninsula of New Guinea, Stein et al. (1993) reported two clusters of ages for reef VIIb, which is also correlated with marine oxygen isotope substage 5e. The older group ranges from ca. 136 to $132 \mathrm{ka}$ whereas the younger group ranges from ca. 119 to $116 \mathrm{ka}$. The majority of coral ages from the Eel Point terrace on San Clemente Island (ca. 128-114 ka, with all but one 123-114 ka) and the Sea Cave terrace on Punta Banda (ca. 123-114 ka) 
Figure 7. Map of northern San Clemente Island showing Quaternary deposits, inferred inner edges of marine terraces (mapped by the authors, modified from Muhs, 1983), and fossil localities at Eel Point.

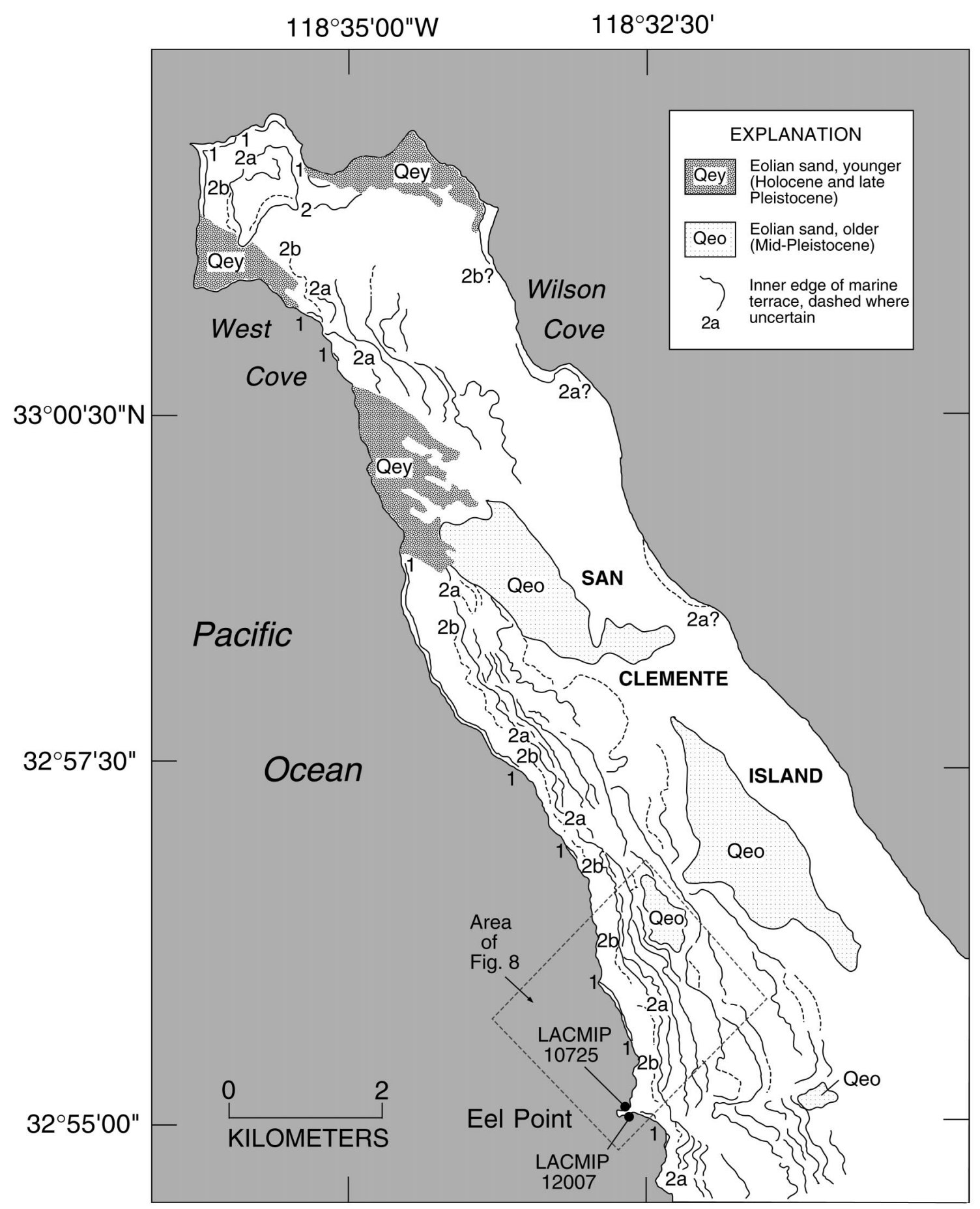

overlap the youngest range of ages found on Barbados and New Guinea.

There are also numerous U-series ages from tectonically stable or very slowly uplifting coastlines such as the Bahamas, Hawaii, and Western Australia. Emergent reefs on San Salvador Island and Grand Inagua Island in the Bahamas have corals in growth position at elevations of up to $5 \mathrm{~m}$. U-series ages of these corals reported by Chen et al. (1991) range from ca. 130 to ca. $120 \mathrm{ka}$. On other islands of the Bahamas, corals are as young as ca. 110 ka (Muhs et al., 1994a). U-series ages of last interglacial corals from Hawaii range from ca. 133 to $110 \mathrm{ka}$ (Szabo et al., 1994; Muhs et al., 2002). On the mainland coast and islands of tectonically stable Western Australia, emergent reefs and marine deposits are widespread, and the degree of coral preservation is generally high. The tops of most of the emergent reefs at many localities range from $\sim 2$ to $4 \mathrm{~m}$ above sea level. U-series ages of Western Australian corals range from ca. 134 to $116 \mathrm{ka}$ (Zhu et al., 1993; Collins et al., 1993; Stirling et al., 1995, 1998).

We conclude that the ages of last interglacial corals from San Clemente Island, Punta Banda, and Isla de Guadalupe overlap with the ranges of ages of hermatypic colonial corals from the tropics (Figs. 12 and 13). From the 
Figure 8. Detailed map and aerial photograph of the Eel Point area, showing marineterrace inner edges (mapped by the authors, modified from Muhs, 1983).
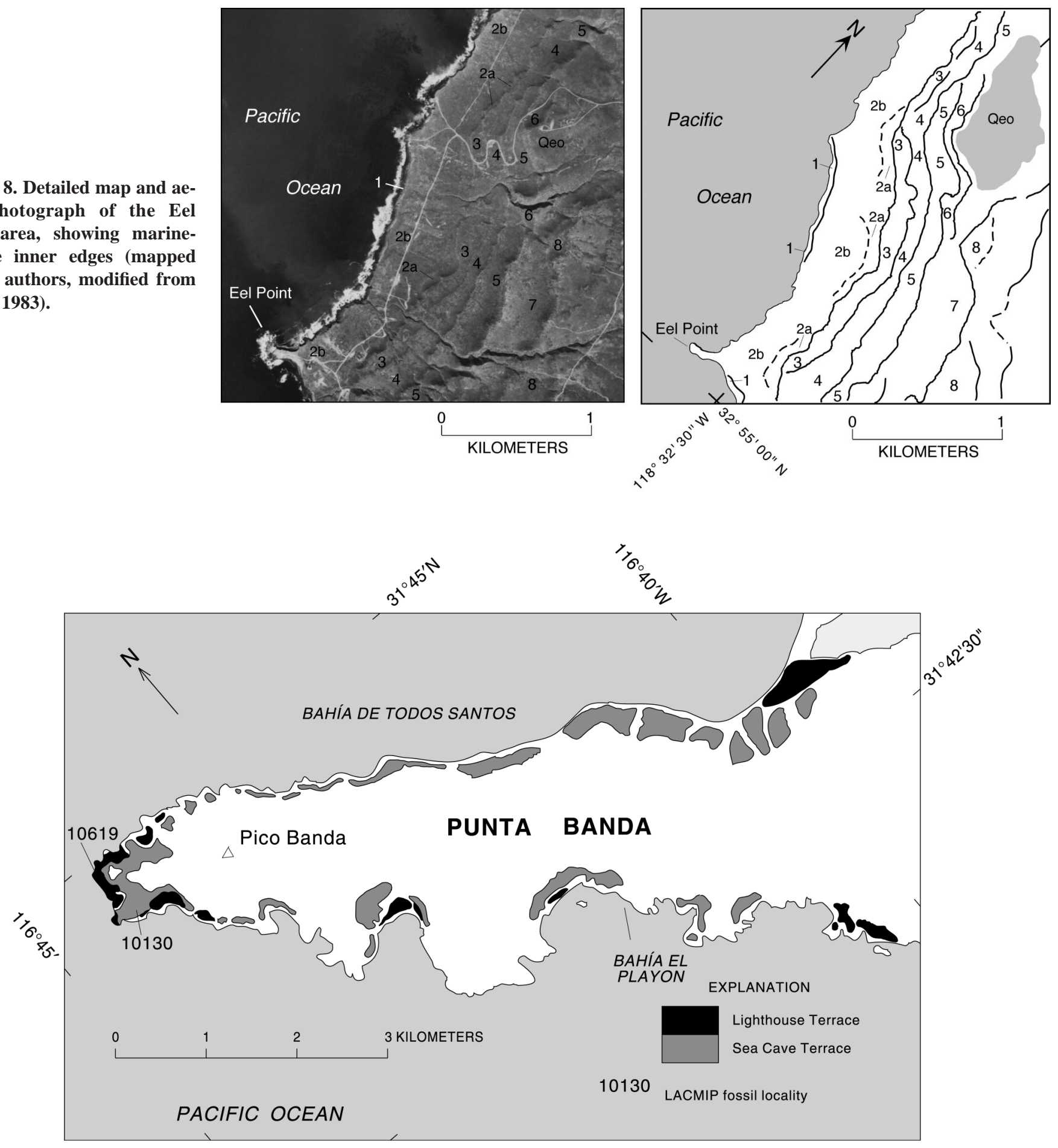

Figure 9. Map showing extent of the lowest two marine terraces on Punta Banda, Baja California, and fossil localities. Mapped by the authors, slightly modified from Rockwell et al. (1989).

three Pacific Coast localities, 27 corals with acceptable initial ${ }^{234} \mathrm{U} / 238 \mathrm{U}$ values showed no ages greater than ca. $123 \mathrm{ka}$, and some are as young as ca. $114 \mathrm{ka}$. This $\sim 9 \mathrm{k}$.y. span of time overlaps with the youngest ages of corals on all tropical coastlines, whether tectonically ris- ing or stable. The results support the model proposed by Bradley and Griggs (1976), shown in Figure 2, in that Pacific Coast marine-terrace deposits are recording the final stage of the last interglacial sea-level highstand. Key to the support of this conclusion is the model of Neumann and MacIntyre (1985), in which they point out that "keep-up" reefs, such as barrier or fringing reefs found on Barbados, New Guinea, and the Bahamas, should have the earliest reef growth during an interglacial. This concept is based on the obser- 
vation that shallow-water corals, such as $A c$ ropora palmata, grow rapidly enough to keep pace with rising sea level (Buddemeier and Smith, 1988).

Numerous ages of ca. 116-114 ka from the Pacific Coast of North America, Hawaii, and the Bahamas show that sea level must have been relatively high during a time that has been considered to be a period of global icesheet growth, i.e., deep-sea oxygen isotope substage 5d (Martinson et al., 1987). This time period coincides with the lowest summer insolation at northern high latitudes of the past 200 k.y. (Figs. 12 and 13). Coral ages reported here and elsewhere challenge the view that there was significant ice growth in the period from ca. 116 to $114 \mathrm{ka}$. Studies of deep-sea cores from the North Atlantic have suggested that relatively warm, interglacial-like conditions existed not only during substage $5 \mathrm{e}$, but persisted well into substage 5d (McManus et al., 1994; Kukla et al., 1997; Broecker, 1998; Kukla, 2000).

\section{Later Sea-level Highstands During the Last Interglacial Period}

The new coral ages presented here provide the first substantial evidence for a sea-level highstand on the Pacific Coast of North America at ca. $105 \mathrm{ka}$, as recorded by the Ventnor terrace on Barbados and reef VI on New Guinea. Although initial ${ }^{234} \mathrm{U} / 238 \mathrm{U}$ values are high, both the Cayucos terrace and the Nestor terrace on Point Loma have corals that are likely ca. $105 \mathrm{ka}$, mixed with older corals that are likely ca. $120 \mathrm{ka}$. These data raise the question of how high sea level was during the ca. 105 ka sea-level highstand.

There are significant differences in estimates of paleo-sea levels for the ca. 105 and ca. 80 ka sea-level highstands. On Barbados, paleo-sea levels of about $-20 \mathrm{~m}$ are estimated for both the ca. 105 and ca. $80 \mathrm{ka}$ sea stands by Bard et al. (1990). On New Guinea, Chappell and Shackleton (1986) estimated paleosea levels of about $-18 \mathrm{~m}$ at ca. $105 \mathrm{ka}$ and about $-16 \mathrm{~m}$ at ca. $80 \mathrm{ka}$. The sea-level estimates for both Barbados and New Guinea were calculated by using assumptions of a paleo-sea level of $+6 \mathrm{~m}$ at ca. $120 \mathrm{ka}$ and a constant uplift rate. By using the same method, Ota and Omura (1992) reported that on Hateruma Island (Japan), sea level at ca. $105 \mathrm{ka}$ could have been about $-3 \mathrm{~m}$ and sea level at ca. 80 ka could have been near the present height. The latter estimate is in agreement with data from tectonically stable Bermuda, Florida, and the Atlantic Coastal Plain of the eastern United States, where there are numerous ca. $80 \mathrm{ka}$

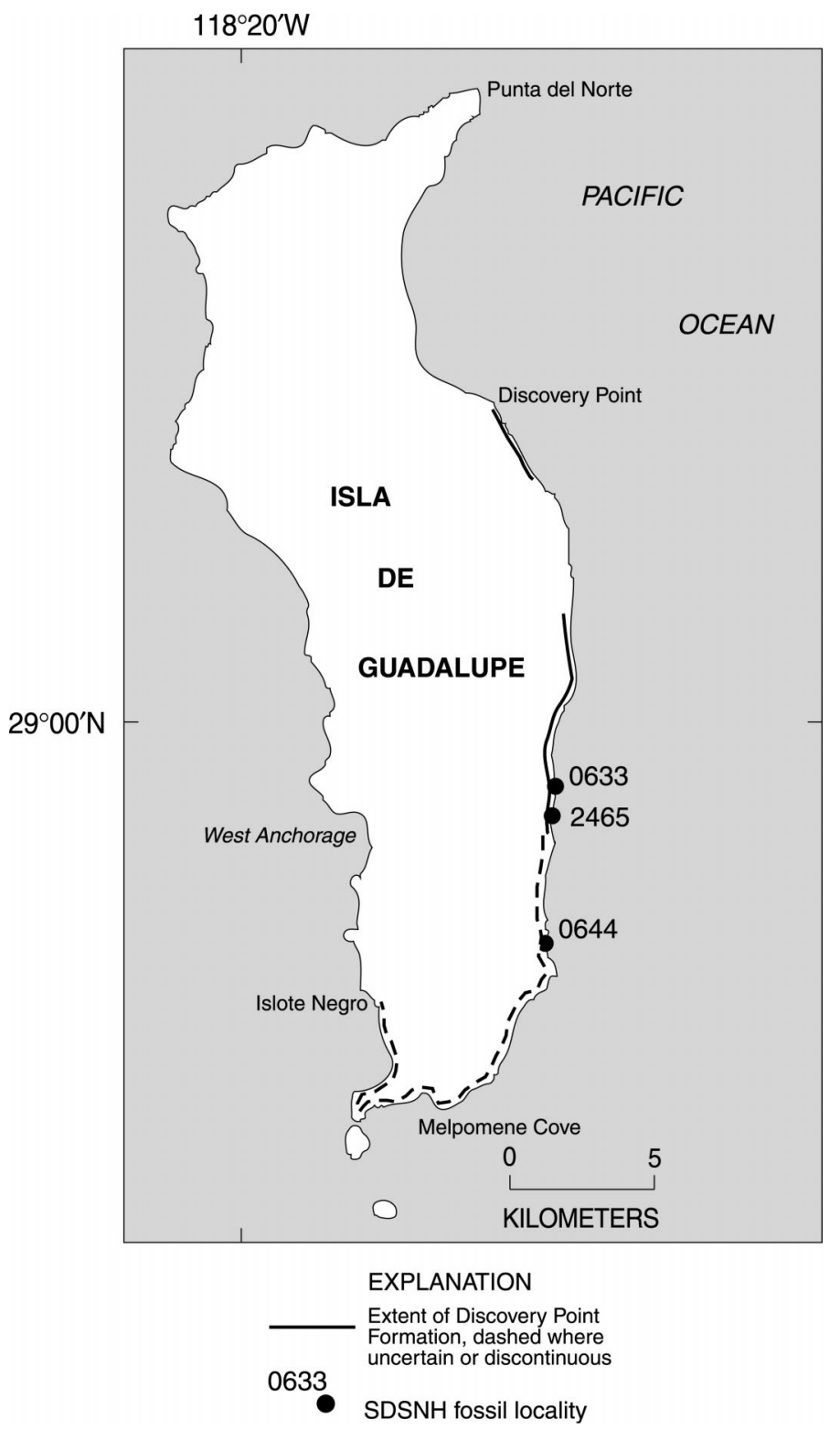

Figure 10. Map showing inferred extent of the Discovery Point Formation marine-terrace deposit and fossil localities on Isla de Guadalupe, Baja California. Extent of marineterrace deposits inferred by the authors from data in Lindberg et al. (1980).

U-series ages of corals from deposits above or near present sea level (Szabo, 1985; Ludwig et al., 1996; Wehmiller et al., 1997; Muhs et al., 2002). On the Pacific Coast, the only locality that allows independent calculations of paleo-sea levels at these times is Punta Banda. The U-series ages presented here indicate that the Sea Cave terrace (shoreline angle elevation of $\sim 34 \mathrm{~m}$ ) has only ca. $120 \mathrm{ka}$ corals and the Lighthouse terrace (shoreline angle elevation of $\sim 16 \mathrm{~m}$ ) has only ca. $80 \mathrm{ka}$ corals. We infer, on the basis of these ages and correlation to Barbados and New Guinea, that the intermediate, $\sim 22 \mathrm{~m}$ terrace on Punta Banda corre- sponds to the $105 \mathrm{ka}$ sea-level highstand, as suggested by Rockwell et al. (1989). If this is the case, then calculation of paleo-sea levels using the constant-uplift-rate method yields estimates of about $-2 \mathrm{~m}$ and about -3 to -4 $\mathrm{m}$ for the 105 and $80 \mathrm{ka}$ sea-level highstands, respectively. Finally, paleo-sea levels can be calculated from terrace data by a means other than the constant-uplift-rate method. Bloom and Yonekura (1985) used the same terrace data presented in Bloom et al. (1974) for New Guinea and calculated paleo-sea levels with a graphical method that is mathematically different from the constant-uplift-rate method. 


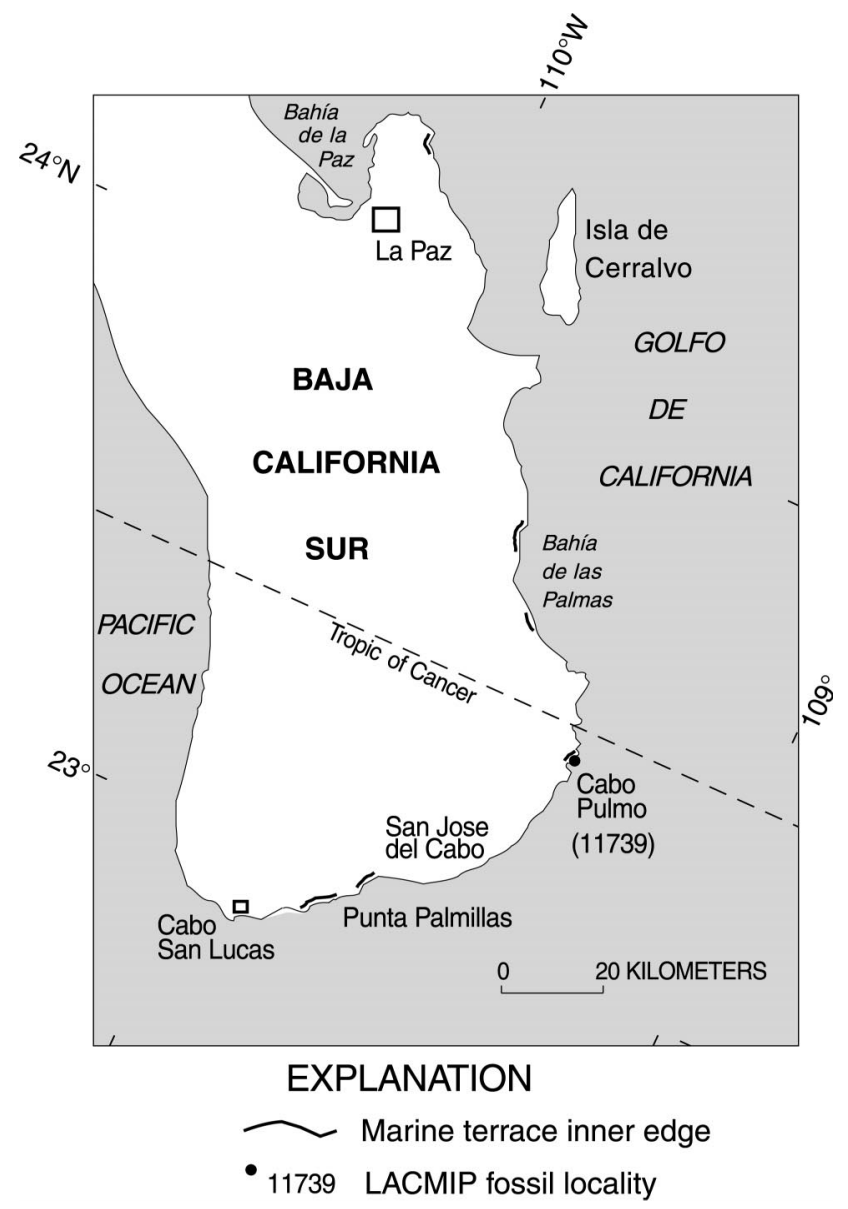

Figure 11. Map showing extent of marine-terrace deposits in southernmost Baja California Sur (from Ortlieb, 1987) and fossil locality in the Cabo Pulmo area.

Their results suggested that sea level at ca. $105 \mathrm{ka}$ could have been close to the present height and sea level at ca. 80 ka could have been about $-7 \mathrm{~m}$.

If the estimates of sea level close to the present height at ca. $105 \mathrm{ka}$ are correct, then the mixtures of apparent ca. $105 \mathrm{ka}$ and ca. 120 ka corals on the Cayucos terrace and Nestor terrace are explained. The observations made here suggest that in areas of relatively low uplift rate, at least the distal (seaward) part of a terrace created by the ca. $120 \mathrm{ka}$ sea-level highstand was later reoccupied by the sea-level highstand of ca. $105 \mathrm{ka}$. The shoreline angle elevation of the Cayucos terrace is only $\sim 7-$ $8 \mathrm{~m}$ and is therefore barely above the maximum elevation of the ca. $120 \mathrm{ka}$ sea-level highstand, on the basis of last interglacial reef elevations from tectonically stable coastlines and islands such as Isla de Guadalupe (reported here), the Bahamas (Chen et al., 1991; Muhs et al., 1994a), and Western Australia (Zhu et al., 1993; Collins et al., 1993; Stirling et al., 1995, 1998). Thus, if the sea-level stand of ca. $105 \mathrm{ka}$ were near the present height, the probability is high that it would reoccupy at least a part of the terrace created by the ca. $120 \mathrm{ka}$ stand at Cayucos. The uplift rate at Point Loma, although higher than that at $\mathrm{Ca}$ yucos, is still low compared to that for Punta Banda. Thus, the sea-level highstand of ca. 105 ka may also have partially reoccupied the ca. $120 \mathrm{ka}$ platform at Point Loma before much uplift took place. If the estimates of an approximately $-20 \mathrm{~m}$ sea level for the ca. 105 ka sea level are correct (e.g., Bard et al., 1990), then it is more difficult to explain the mixture of fossils on the Cayucos and Nestor terraces, unless highly nonlinear tectonics are invoked.

At Punta Banda, six Balanophyllia samples from the Lighthouse terrace yielded reliable U-series ages that range from ca. 83 to $80 \mathrm{ka}$ and, as already indicated, suggest a paleo-sea level no more than a few meters below that at present. There are few reliable TIMS U-series ages from the correlative Worthing terrace (a "keep-up" reef) on Barbados for age compar- isons, but those that exist (and that have at least marginally acceptable initial ${ }^{234} \mathrm{U} / 238 \mathrm{U}$ values) are somewhat older than the Lighthouse terrace corals (Fig. 14). This difference is similar to that between the older Sea Cave (Punta Banda) and Rendezvous Hill (Barbados) terraces (Fig. 13). In contrast, the ages of corals from Bermuda (derived from what was probably a "catch-up" patch reef) reported by Ludwig et al. (1996) and Muhs et al. (2002) are similar to those from the Lighthouse terrace on Punta Banda (Fig. 14). Thus, we hypothesize that terraces on the Pacific Coast that were generated during the ca. $80 \mathrm{ka}$ sealevel highstand may also record the final stages of this later high sea level. High-precision dating of corals from other localities that have ca. 80 ka corals (see Muhs et al., 1994b) could provide a more rigorous test of this hypothesis.

\section{Paleozoogeography and Marine Temperatures During Last Interglacial Sea-level Highstands}

Fossil mollusks from marine terraces provide a powerful tool for estimating marine paleotemperatures during interglacial sea-level highstands (Kennedy, 2000). Before modern geochronological methods were developed, however, a persistent question in the paleontological community was why there were apparent mixtures of extralimital northern and southern species (i.e., species whose northern or southern range endpoints are beyond the study area) in what were perceived to be marine deposits of similar age. Critical to this apparent contradiction was an assumption that the lowest marine-terrace deposits at all localities along the Pacific Coast were of similar age. For example, Arnold (1903), Woodring (1935, 1957), Woodring et al. (1946), Valentine (1961), and Valentine and Meade (1961) have all pointed out that deposits of the "first" terrace in northern San Pedro, California, have a distinct warm-water fauna, whereas deposits of the "first" terrace in central and southern San Pedro have a distinct cool-water fauna. These workers proposed various mechanisms to explain this geographic zonation including upwelling, transportation of the coolwater species from greater depths by storm waves, reworking from older units, and changes in depth or temperature tolerances. Aminostratigraphic studies (Wehmiller et al., 1977; Kennedy et al., 1982) with good paleontological characterization showed that the assumption of an identical age for the lowest marine terrace all along the Pacific Coast is incorrect and that terrace deposits with cool- 
MUHS et al.
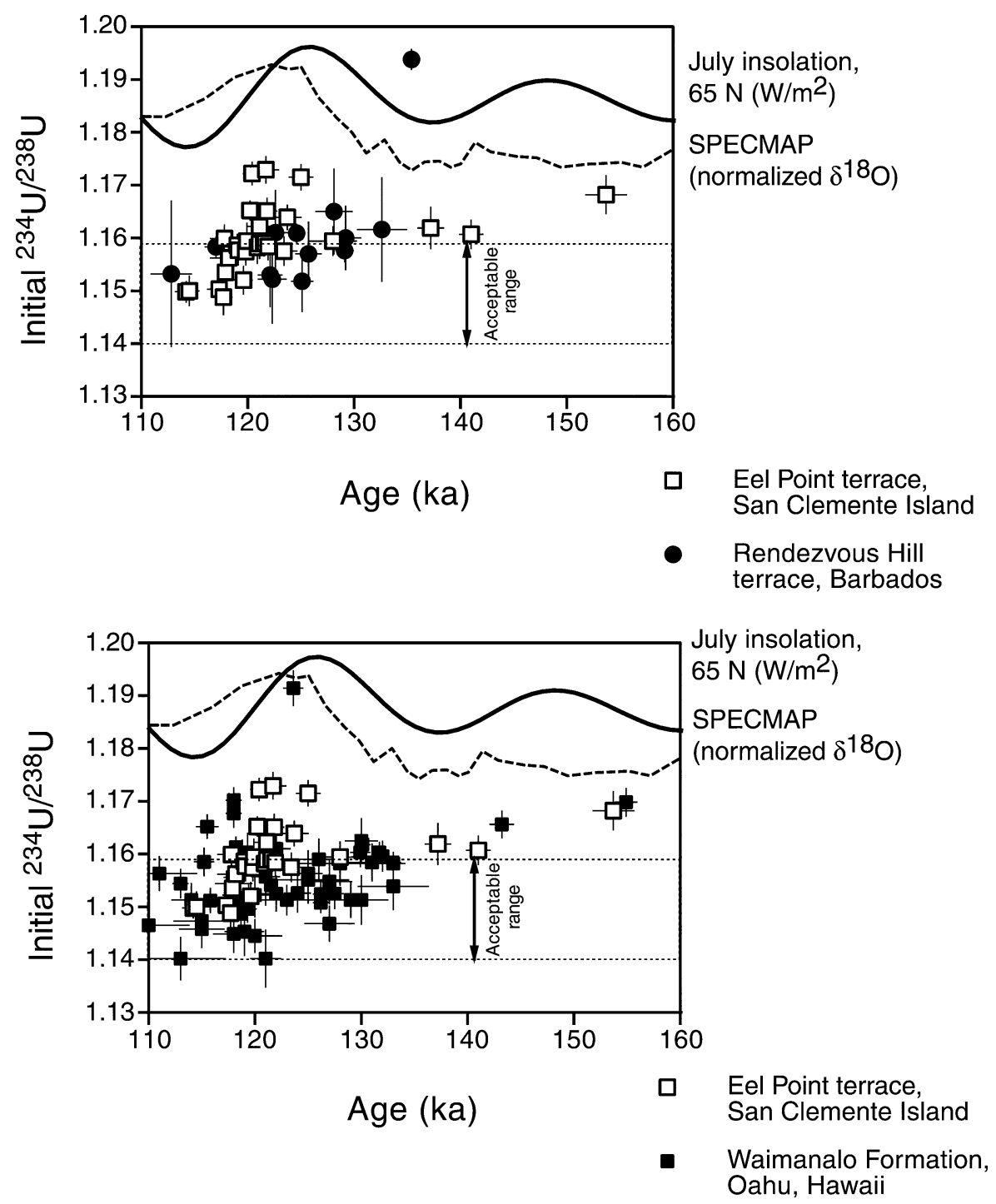

Figure 12. Ages of marine-terrace corals from the Eel Point terrace (San Clemente Island), the Rendezvous Hill terrace (Barbados), and the Waimanalo Formation (Oahu, Hawaii), shown as a function of initial ${ }^{234} \mathrm{U} /{ }^{238} \mathrm{U}$ values. Shown for comparison are curves of July insolation at $65^{\circ} \mathrm{N}$ (from Berger and Loutre, 1991) and the generalized SPECMAP oxygen isotope record (from Martinson et al., 1987). San Clemente Island data from this study; Barbados data from Edwards et al. (1987, 1997), Bard et al. (1990), Hamelin et al. (1991), and Gallup et al. (1994); Oahu data from Szabo et al. (1994) and Muhs et al. (2002).

water faunas are probably correlative with substage $5 \mathrm{a}$ or $5 \mathrm{c}$ and those with neutral or warmwater faunas are probably correlative with substage 5e (Kennedy, 1978; Kennedy et al., 1982) Subsequent alpha-spectrometric U-series dating of corals from many of these terraces confirmed the aminostratigraphic interpretations (Muhs et al., 1990, 1994b).

Despite the explanation of differing ages for most cool vs. warm faunal localities on the Pacific Coast, some localities still showed apparently contradictory mixtures of cooler- and warmer-water species. Examples include the
On Isla de Guadalupe, the Discovery Point Formation has ages of ca. 123-118 ka, and the island has no higher terraces as a source of older, reworked fossils. We plotted the geographic ranges of extralimital or northwardand southward-ranging species from this formation (reported by Lindberg et al., 1980) in Figure $15 .{ }^{1}$ Although two species range mainly to the north of Isla de Guadalupe, both live around the island today. All other species shown in Figure 15 are strictly extralimital southern species, and the majority of these have ranges that extend into or beyond the Surian and Panamic provinces (Fig. 1). The Discovery Point Formation even has a gastropod, Cypraea cernica [Erosaria cernica (Sowerby, 1870)], that currently lives only in the Indo-Pacific province, from South Africa to Easter Island (Lorenz and Hubert, 2000). The closest living occurrence of this species to North America may be Hawaii (Kay, 1979); if so, the Discovery Point occurrence represents a range extension of $>4000 \mathrm{~km}$. Lindberg et al. (1980) interpreted these warmer-water species to indicate last interglacial waters at least seasonally warmer than those that occur around Isla de Guadalupe today. Indeed, the very presence of the hermatypic coral Pocillopora, dated here, is indicative of warmer-than-modern waters. The closest living species of Pocillopora is found at Cabo San Lucas (Fig. 11), >1100 km to the southeast of Isla de Guadalupe (Wilson, 1988). On the Pacific Coast of the Americas, Pocillopora lives only from Cabo San Lucas southward to Ecuador.

At Punta Banda, there is no evidence of reworking of corals in either the ca. $120 \mathrm{ka}$ Sea Cave terrace or the ca. 80 ka Lighthouse terrace. Fossil localities of the Sea Cave terrace are found on both sides of Punta Banda (Rockwell et al., 1989). However, modern water temperatures differ significantly in these two areas owing to strong seasonal upwelling on the exposed, southwestern side (Hubbs and Roden, 1964). Thus, fossil localities of the Sea Cave terrace on the two sides of Punta Banda also differ markedly in their faunal compositions. On the cooler, southwestern, open-ocean side of Punta Banda, Rockwell et al. (1989) reported no extralimital northern or southern species. However, the protected, northeastern side of Punta Banda is bathed by the warm waters of Bahía de Todos Santos. Last interglacial faunas from this side of Punta Banda

${ }^{1}$ GSA Data Repository item 2002060, modern geographic ranges of fossils, is available on the Web at http://www.geosociety.org/pubs/ft2002.htm. Requests may also be sent to editing@geosociety.org. 


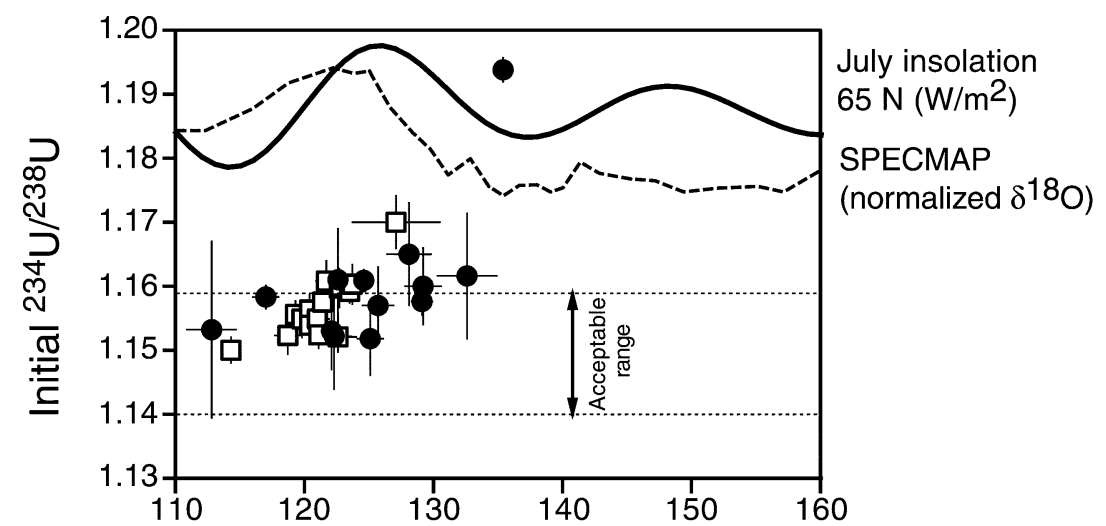

Age (ka)

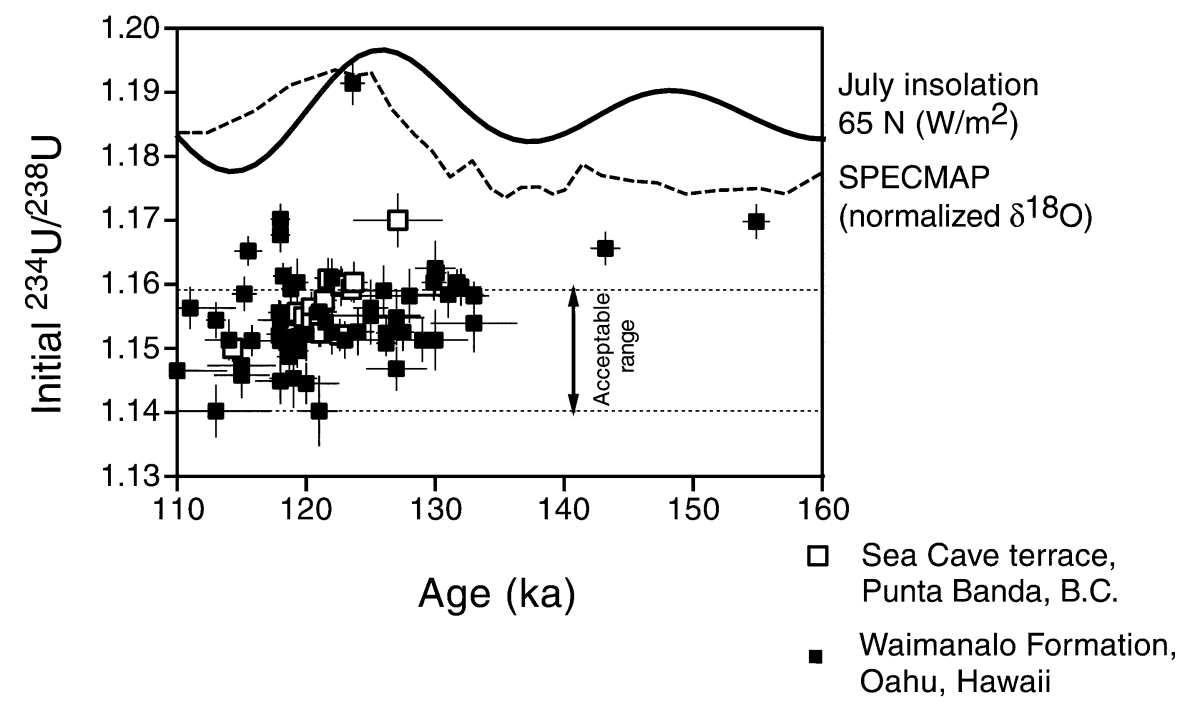

Figure 13. Ages of marine-terrace corals from the Sea Cave terrace (Punta Banda, Baja California), the Rendezvous Hill terrace (Barbados), and the Waimanalo Formation (Oahu, Hawaii), shown as a function of initial ${ }^{234} U /{ }^{238} U$ values. Shown for comparison are curves of July insolation at $65^{\circ} \mathrm{N}$ (from Berger and Loutre, 1991) and the generalized SPECMAP oxygen isotope record (from Martinson et al., 1987). Punta Banda data from this study; Barbados data from Edwards et al. (1987, 1997), Bard et al. (1990), Hamelin et al. (1991), and Gallup et al. (1994); Oahu data from Szabo et al. (1994) and Muhs et al. (2002).

contain one southward-ranging (Acanthina lugubris) and two extralimital southern (Macron aethiops and Stramonita biserialis) species (Fig. 16). Modern A. lugubris has an extreme range as far north as Newport Bay, California, but typically ranges no farther north than San Diego (Abbott, 1974); at Punta Banda it is therefore near its northern limit. Stramonita biserialis ranges no farther north than Isla de Cedros. Both species have modern ranges that extend southward into the Panamic province
(Fig. 1). Thus, whereas the fossils in the Sea Cave terrace deposits do not contain as many extralimital southern species as the Discovery Point Formation, those present are still indicative of warmer-than-modern waters at the time of the ca. $120 \mathrm{ka}$ sea-level highstand.

In contrast to that of the Sea Cave terrace, the ca. $80 \mathrm{ka}$ Lighthouse terrace fauna lacks extralimital southern species but does contain five extralimital northern species and two northward-ranging species (Fig. 16). The ex- tralimital northern species span the Californian, Oregonian, and even Aleutian provinces (Fig. 1). These data indicate that during the ca. 80 ka sea-level highstand, waters off Punta Banda were considerably cooler than at present. The observation of cooler waters at ca. $80 \mathrm{ka}$ is consistent with other data from the Pacific Coast of North America, at least as far north as southern Oregon (Kennedy, 1978; Kennedy et al., 1982, 1992; Muhs et al., 1990), the northernmost dated 80 ka terrace in North America.

On San Clemente Island, the ca. $120 \mathrm{ka}$ Eel Point terrace has a typical exposed, opencoast, rocky-shore fossil assemblage. The terrace fauna from this locality has not been reported previously, and a full analysis of the species is beyond the scope of the present study. However, it is worth noting that in the fauna from Eel Point, all the bivalves (Crassadoma gigantea, Cumingia californica, Epilucina californica, Glans subquadrata, and Mytilus californianus) and most of the gastropods (Acmaea mitra, Conus californicus, Crepipatella dorsata, Diodora aspera, Fisurella volcano, Haliotis cracherodii, Megathura crenulata, Norrisia norrisi, Tegula funebralis, Zonaria spadicea, and five species of Lottia) have modern ranges that extend well to the north and south of San Clemente Island. Some, such as Lottia digitalis and Crassadoma gigantea, have ranges that span the Aleutian to Surian provinces. It is important, however, to note that the deposit does not contain any extralimital northern species. In addition, two gastropods, Acanthina lugubris and Stramonita biserialis (reported by Kennedy et al., 1995), are north of their known modern, exposed-coastal range limit (San Diego and Isla de Cedros, respectively) and suggest warmerthan-modern climatic conditions.

Identification of a warm-water signature for deposits with confidently dated ca. 120 ka corals and a cool-water signature for deposits with confidently dated ca. 80 ka corals may explain the coexistence of warmer- and coolerwater faunas in terrace deposits at Point Loma, Cayucos, and elsewhere on the Pacific Coast. Although there are no prior U-seriesdated ca. 105 ka marine-terrace deposits that also have detailed published faunal data, the second terrace in western Santa Barbara County likely correlates to this sea-level highstand on the basis of geomorphic position and amino-acid ratios in mollusks (Kennedy et al., 1992). These terrace deposits contain four extralimital northern species of mollusks and no extralimital southern species. Thus, if correlation of the second terrace in southwestern Santa Barbara County to the ca. 105 ka high 

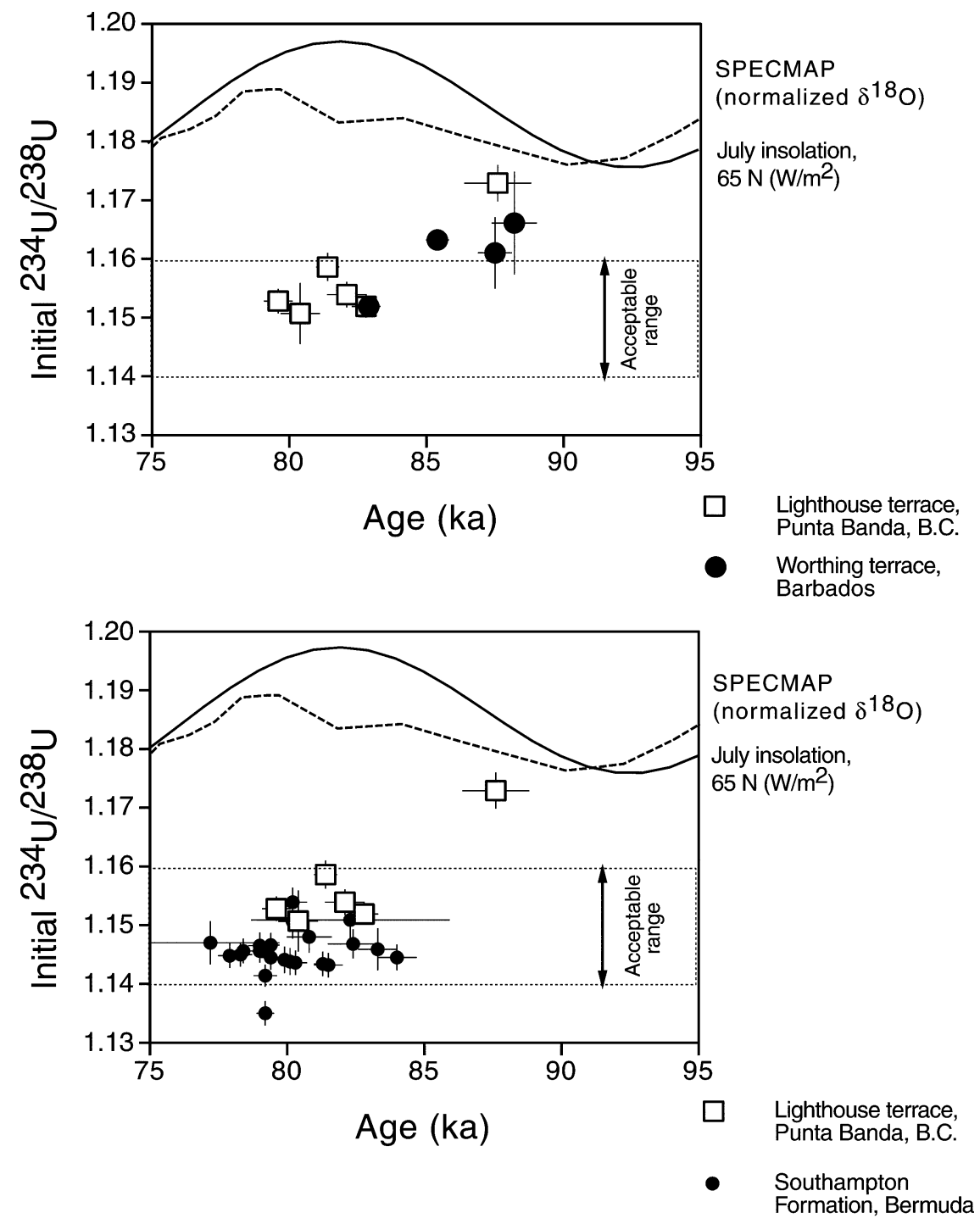

Figure 14. Ages of marine-terrace corals from the Lighthouse terrace (Punta Banda, Baja California), the Worthing terrace (Barbados), and the Southampton Formation (Bermuda), shown as a function of initial ${ }^{234} U / 238 \mathrm{U}$ values. Shown for comparison are curves of July insolation at $65^{\circ} \mathrm{N}$ (from Berger and Loutre, 1991) and the generalized SPECMAP oxygen isotope record (from Martinson et al., 1987). Punta Banda data from this study; Barbados data from Edwards et al. (1987, 1997), Bard et al. (1990), and Gallup et al. (1994); Bermuda data from Ludwig et al. (1996) and Muhs et al. (2002).

stand is correct, then it is likely that the ca. 105 ka high stand, like the ca. 80 ka high stand, was accompanied by cooler-thanmodern waters off the Pacific Coast of North America. Cooler-than-modern waters are also inferred for well-dated ca. $80 \mathrm{ka}$ and $105 \mathrm{ka}$ terraces on New Guinea and Barbados, on the basis of oxygen isotope analyses of mollusks and corals (Aharon and Chappell, 1986; Fairbanks and Matthews, 1978). On New Guinea, cooler-than-modern waters are also inferred for relatively high sea stands (but much lower than at present) recorded between ca. $70 \mathrm{ka}$ and $30 \mathrm{ka}$ (Aharon and Chappell, 1986).

The Nestor terrace at Point Loma contains a mixture of southern and northern species (Fig. 17). Although the Nestor terrace fauna has been described as having a dominance of warmer-water species (e.g., Kern, 1977; Kennedy et al., 1982), updating of the geographic ranges reveals that there are actually more cool-water forms than warm-water forms. Five of the cool-water species found in the Nestor terrace are also found in the Bird Rock terrace, which contains only cooler-water species. However, the Nestor terrace deposits contain eight extralimital southern species and one southward-ranging species. As discussed earlier, the Nestor terrace corals all showed open-system histories, but most have likely ages of $109-100 \mathrm{ka}$ and $136-116 \mathrm{ka}$, if the secondary $U$ and Th uptake model of Gallup et al. (1994) is correct. We hypothesize that the warm-water species in the Nestor terrace deposits date to the older sea-level highstand (136-116 ka) and the cool-water species date to the younger sea-level highstand (109-100 ka).

A similar interpretation can be made for the mixture of warm- and cool-water species found in deposits of the Cayucos terrace (Fig. 18 ). On the basis of updated modern geographic ranges, this deposit has more extralimital forms than originally suggested by Valentine (1958). Acmaea persona, Nucella lamellosa, and Velutina velutina are all extralimital northern species, and Alvania montereyensis and Nucella canaliculata are both northward-ranging species. In contrast, Crepidula incurva, C. onyx, Diodora inaequalis, Rissoina coronadoensis, Serpulorbis squamiger$i$, and Semele decisa are all extralimital southern species. In addition to these strictly extralimital southern species, the Cayucos terrace deposits contain an additional 12 southwardranging species whose northern range limits occur either at Cayucos or only slightly farther north, at Monterey. As with the Nestor terrace, the Cayucos terrace deposits contain corals that have been subject to open-system conditions, but most have estimated ages that fall into two groups: ca. 108-102 ka and ca. 133114 ka. Again, we hypothesize that the warmwater forms may date to the earlier highstand and the cool-water forms may date to the later highstand during a period of terrace reoccupation.

Roy et al. (1995) suggested that on the Pacific Coast of North America during the Pleistocene, water-mass boundaries may have been more effective barriers for southern species migrating north than for northern species moving south. This hypothesis could explain the decrease in the number of extralimital southern species in ca. $120 \mathrm{ka}$ deposits moving from south to north, from Isla de Guadalupe to Punta Banda to San Clemente Island. The model is also consistent with the observation of approximately similar numbers of extralimital northern species in ca. $80 \mathrm{ka} \mathrm{de-}$ posits regardless of latitude. For example, the lowest marine terrace at Coquille Point in Bandon, Oregon, is dated to ca. $80 \mathrm{ka}$ (Muhs et al., 1990). Kennedy (1978) reported that 


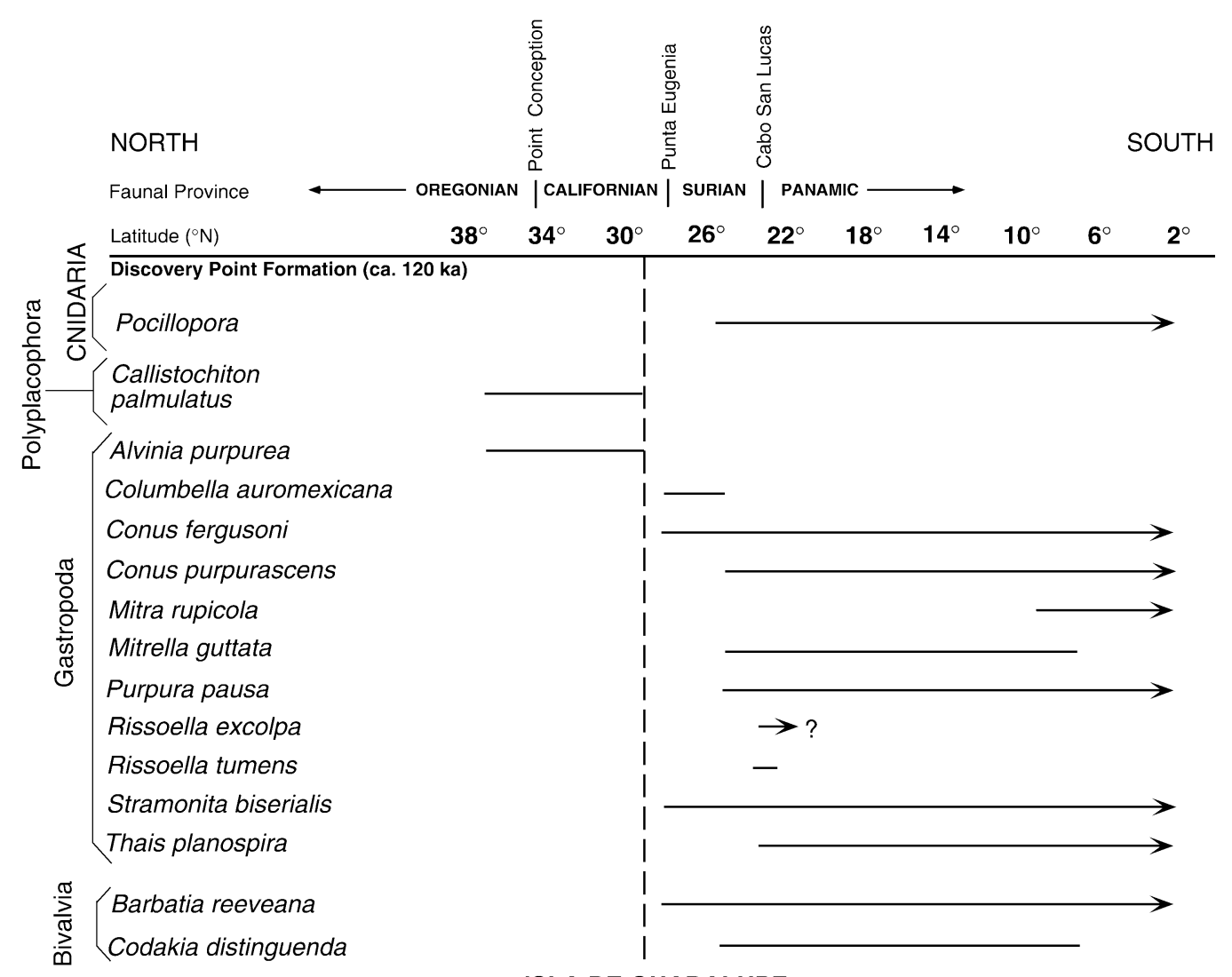

ISLA DE GUADALUPE

Figure 15. Modern geographic ranges of extralimital species, i.e., species whose northern or southern range endpoints are beyond or near the study area, from the ca. 120 ka Discovery Point Formation, Isla de Guadalupe, Baja California. Species are from Lindberg et al. (1980); range of Pocillopora is from Wilson (1988), and ranges of molluscan species are from Keen (1971). See Data Repository Table A (see footnote 1) for detailed information on ranges and sources.

these southern Oregon terrace deposits have about the same number of extralimital northern species as found in the ca. 80 ka Lighthouse terrace deposits in northern Baja California. However, Cayucos and Point Loma are both farther north than Punta Banda, and Cayucos is also farther north than San Clemente Island. Last interglacial terraces at Point Loma and Cayucos both have a greater number of extralimital southern species than last interglacial terraces on Punta Banda or San Clemente Island, an observation that does not support the hypothesis of Roy et al. (1995). However, a better test might be to examine the fossil record of ca. $120 \mathrm{ka}$ terrace deposits, if they can be found, in northern California or Oregon.

Northward extension of warmer-water species during the ca. 120 ka sea-level highstand is documented with localities discussed in the present study and those reported by other investigators. In Figure 19, we show terrace localities in southern California and Baja California that contain the warm-water gastropods
Acanthina lugubris and Stramonita biserialis. All but three of these localities have corals with ca. 120 ka ages; the other three localities (Santa Barbara, San Pedro, and Bahía de Tortugas) have amino-acid ratios in fossil mollusks that allow correlation to nearby, welldated $120 \mathrm{ka}$ deposits. These two gastropods are found in 120 ka deposits in Baja California Sur, south of their modern northern range limits, which is not surprising. However, A. lugubris is also found in $120 \mathrm{ka}$ terrace deposits at five localities at or north of its modern northern limit (near San Diego), and S. biserialis is found at five $120 \mathrm{ka}$ localities north of its modern northern limit (Isla de Cedros). These occurrences indicate last interglacial northward range extensions, relative to present ranges, of $>300 \mathrm{~km}$ for $A$. lugubris and $>600$ $\mathrm{km}$ for $S$. biserialis. We interpret the warmerwater conditions represented by these species during the last interglacial period to be the result of decreased strength of the cool California Current. It can be hypothesized that, at least during part of the year, the last intergla- cial ocean off southern California and Baja California may have had a greater component of water derived from the tropical eastern $\mathrm{Pa}$ cific. Coan et al. (2000) reported that during El Niño years, when tropical eastern Pacific waters reach southern California, species that are usually present only off Baja California are found much farther north. A weaker California Current, with a greater frequency of $\mathrm{El}$ Niño years than is the case at present, may have characterized much of the last interglacial period.

\section{Comparison of Marine-Terrace Faunas with Other Records of Marine Paleotemperatures}

One of the most important developments in eastern Pacific paleoceanography has been the successful recovery of long sediment cores with detailed Quaternary paleoclimate records from basins off the California coast (Kennett, 1995; Kennett and Venz, 1995; Herbert et al., 1995, 2001; Kreitz et al., 2000; Mangelsdorf 


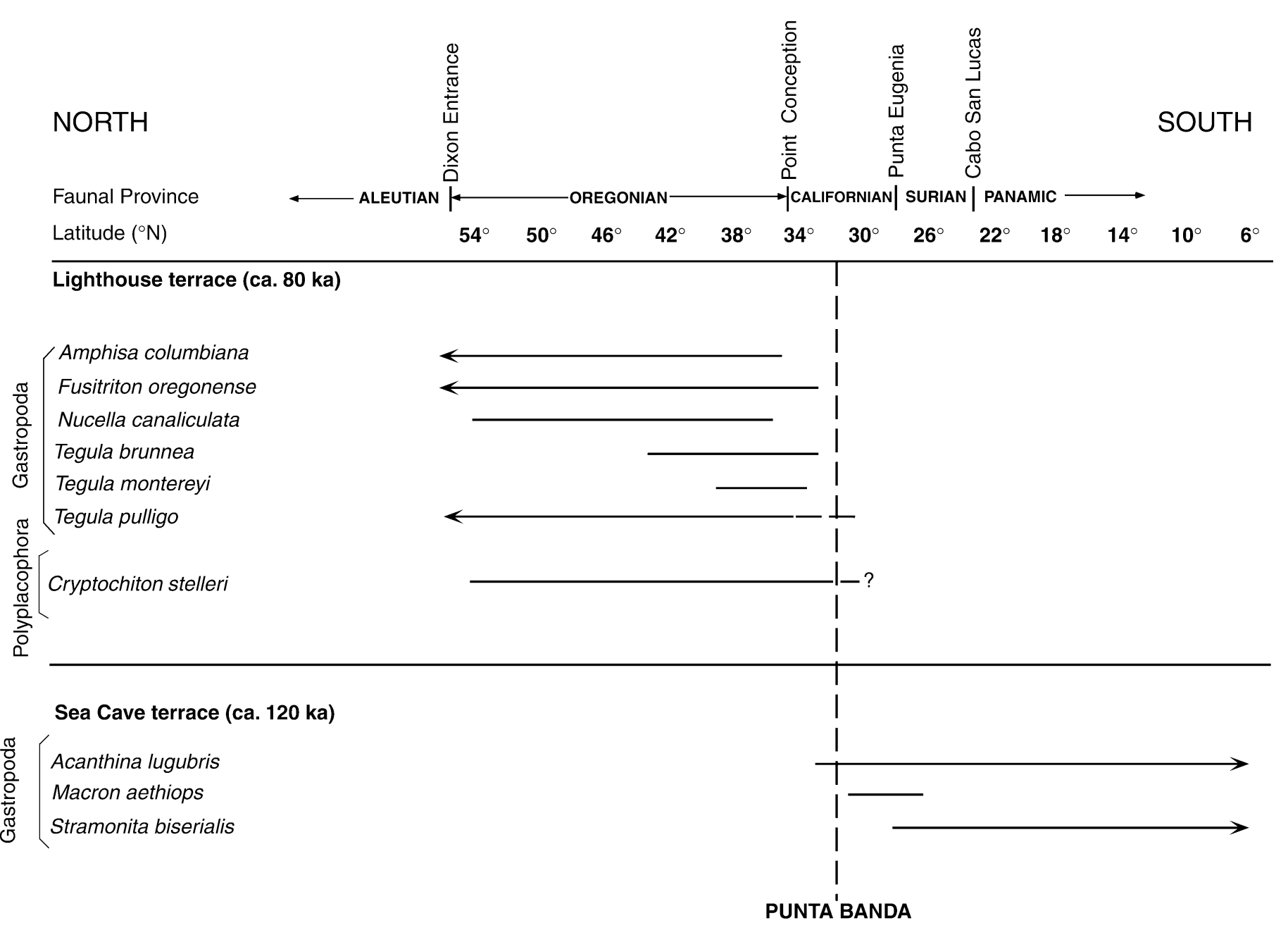

Figure 16. Modern geographic ranges of extralimital and northward- or southward-ranging species from the ca. 120 ka Sea Cave terrace and the ca. 80 ka Lighthouse terrace on Punta Banda, Baja California. Species and geographic ranges are from Rockwell et al. (1989). See Data Repository Table A (see footnote 1) for detailed information on ranges and sources.

et al., 2000). Well-characterized cores with high-resolution foraminiferal and alkenone records have been obtained from sites off northern Baja California, San Diego, Santa Barbara, Point Conception, Santa Cruz, Eureka, and Crescent City. The core from Hole 893 in the Santa Barbara Basin has one of the most complete and detailed records studied thus far, and because we have marine-terrace localities both north and south of this site (Fig. 1), we compare our results to this high-resolution record.

Santa Barbara Basin Hole 893 has the familiar benthic oxygen isotope record of marine stages (Fig. 20), from the present interglacial, i.e., stage 1 , back to the penultimate glacial, i.e., stage 6 (Kennett, 1995). The benthic foraminifera oxygen isotope record provides the stratigraphic framework whereas surface-water paleotemperature estimates have been made by using planktonic foraminifera counts (Kennett and Venz, 1995) and alkenone- unsaturation indices in phytoplankton (Herbert et al., 1995). Paleotemperature estimates from foraminifera are derived from relative abundances of dextral-coiling vs. sinistral-coiling Neogloboquadrina pachyderma. Santa Barbara Basin waters are characterized at present by dextral-coiling $N$. pachyderma. Fossil assemblages dominated by this form exist where summer surface-water temperatures are between 10 and $20{ }^{\circ} \mathrm{C}$ (Kennett, 1976). In contrast, sinistral-coiling $N$. pachyderma is characteristic of subarctic waters in the northeastern Pacific Ocean and elsewhere. Populations dominated $(90 \%-100 \%)$ by this form occur in waters that have summer temperatures lower than $6{ }^{\circ} \mathrm{C}$ (Bandy, 1968).

The Santa Barbara Basin record shows that only during the peak of the last interglacial period (substage 5e) and in the Holocene (stage 1) were surface waters dominated by dextral-coiling (warm-water) N. pachyderma
(Fig. 20). During isotope substages $5 c$ and 5a, abundances of dextral-coiling $N$. pachyderma were much lower, and commensurately higher abundances of sinistral-coiling (cool water) $N$. pachyderma are observed (Kennett and Venz, 1995). The alkenone record also shows that substage 5 e was characterized by warm waters, significantly warmer, in fact, than at present (Fig. 20). However, in contrast to the foraminiferal record, the alkenone record suggests that substages $5 \mathrm{c}$ and $5 \mathrm{a}$ were relatively warm, on a par with the present interglacial temperatures of $15-16{ }^{\circ} \mathrm{C}$ in Santa Barbara Basin. Warm waters during these substages are also reported for two cores off northern Baja California, not far from Punta Banda (Herbert et al., 2001).

The reason for the discrepancy between the planktonic foraminiferal and phytoplankton (alkenone) records in Santa Barbara Basin is not understood, but marine-terrace faunas pro- 


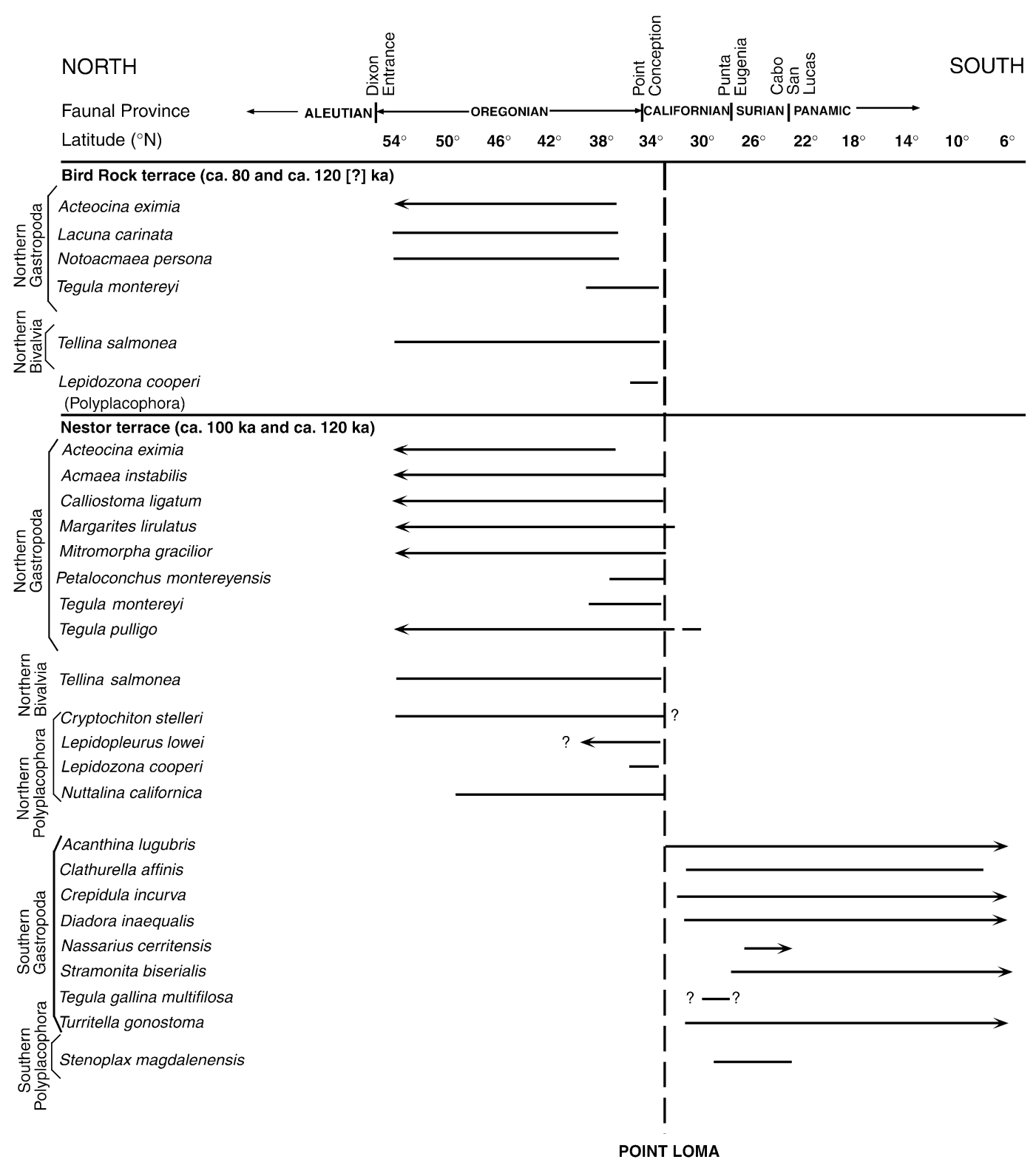

Figure 17. Modern geographic ranges of extralimital and northward- or southward-ranging species from the Nestor and Bird Rock terraces on Point Loma, San Diego, California. Species are from Valentine and Meade (1961) and Kern (1977). See Data Repository Table A (see footnote 1) for detailed information on ranges and sources.

vide an independent record of marine paleotemperatures. The terrace faunal data compiled in this study agree with both Santa Barbara Basin sediment records that substage $5 \mathrm{e}$ was characterized by water temperatures warmer than at present (Fig. 20). According to the alkenone record, marine temperatures during the peak of the last interglacial period in Santa Barbara Basin could have been as warm as $\sim 19{ }^{\circ} \mathrm{C}$, equivalent to modern temperatures off central to southern Baja California (Lynn, 1967). This warmth should have resulted in a greater number of Surian province (Fig. 1) species in marine-terrace deposits of southern California and northern Baja California during at least some part of the last interglacial period. The presence of southern forms, particularly at Isla de Guadalupe and Punta Banda, permits such an interpretation, although we are not certain that water temperatures as far north as Punta Banda were as warm as $\sim 19{ }^{\circ} \mathrm{C}$. However, alkenone-derived temperature estimates of $15-16{ }^{\circ} \mathrm{C}$ during substages $5 \mathrm{a}$ and $5 \mathrm{c}$ are not consistent with marine-terrace faunas that indicate water temperatures at these times significantly cooler than at present. The Lighthouse terrace at Punta Banda and the Bird Rock terrace at Point
Loma (if it contains dominantly ca. $80 \mathrm{ka}$ fossils) indicate much cooler temperatures off southern California and northern Baja California during substage 5a. If the cooler-water forms present in the Nestor and Cayucos terrace deposits date from the ca. $105 \mathrm{ka}$ sealevel highstand, as our U-series ages suggest, then cooler-than-modern waters would also be inferred for isotope substage 5c (Fig. 20). These observations are consistent with the presence of low abundances of dextral-coiling $N$. pachyderma and high abundances of sinistral-coiling $N$. pachyderma. Thus, the benthic foraminiferal and marine-terrace faunal data 


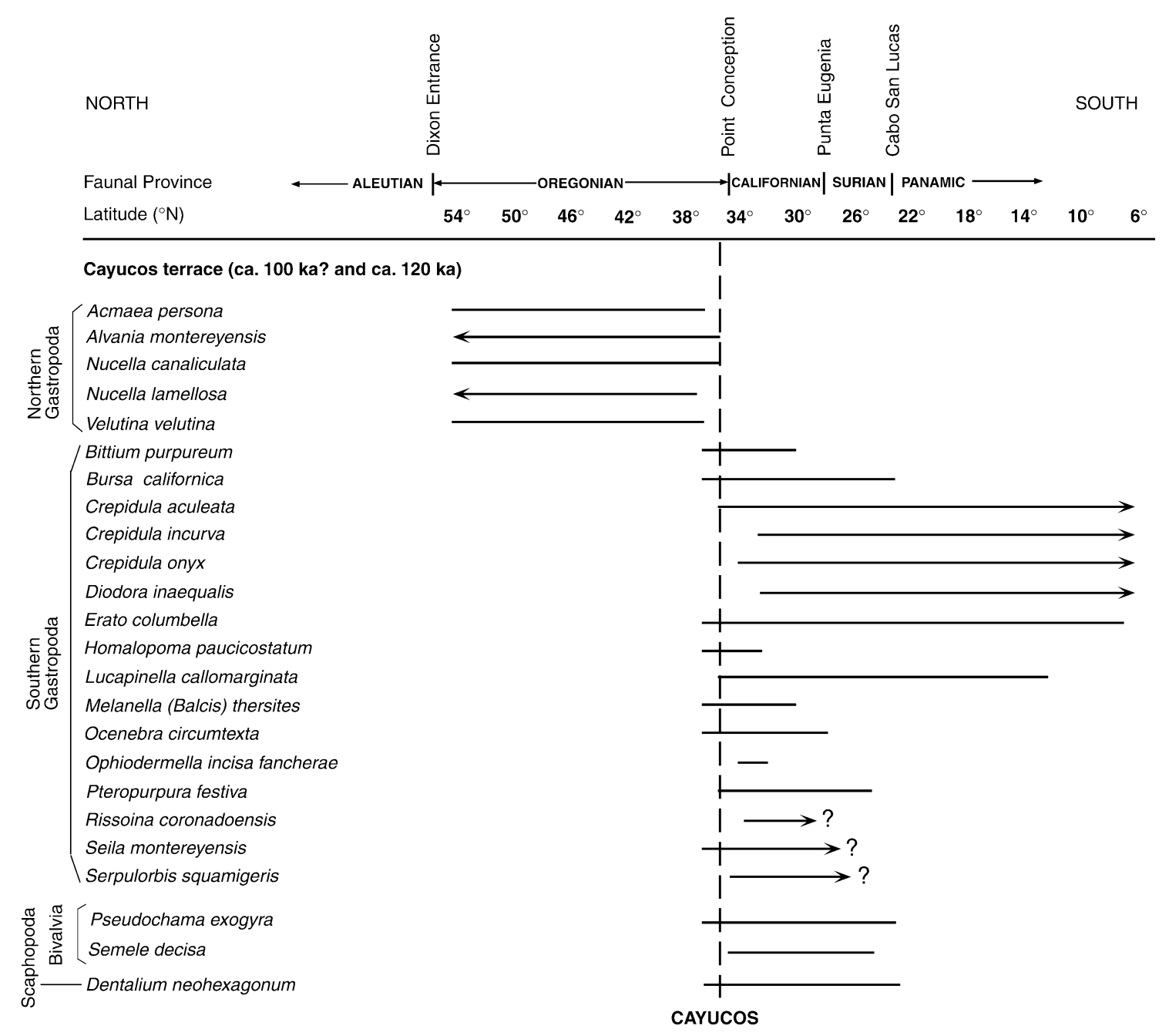

Figure 18. Modern geographic ranges of extralimital species and northward- or southward-ranging species from the Cayucos terrace, California. Species are from Valentine (1958). See Data Repository Table A (see footnote 1) for detailed information on ranges and sources.

suggest that alkenone data may not always faithfully record sea-surface temperatures, at least in an absolute sense. Alternatively, if the warm periods represented by the alkenone record during substages $5 \mathrm{a}$ and $5 \mathrm{c}$ were relatively short-lived, and if marine-terrace deposits on the Pacific Coast record mainly the end, or regressive phase of sea-level highstands (Fig. 2), then a precise concordance between the two records should not be expected.

Alkenone-derived paleotemperature estimates from other core localities off the Pacific Coast (Fig. 1), such as holes 1012 (off northern Baja California), 1017 (off Point Conception), 1018 (off central California), and 1019 and 1020 (both off northern California) have also been reported (Mangelsdorf et al., 2000; Herbert et al., 2001). They all indicate that at least parts of substage 5e were warmer than at present, in good agreement with the Santa
Barbara Basin record. Alkenone records for the main parts of substage 5c (ca. $105 \mathrm{ka}$ ) indicate water temperatures about as warm as at present (Holes 1012 and 1017) and slightly cooler than at present (Holes 1018 and 1020). The alkenone records reported from these cores for substage 5a (ca. $80 \mathrm{ka}$ ) are similarly variable: Holes 1012 and 1019 indicate relatively warm temperatures, whereas Holes 1017, 1018, and 1020 indicate relatively cool temperatures.

For comparison with the younger part of the Santa Barbara Basin record, there is only a single dated, Pleistocene marine-terrace locality younger than substage 5 a that has a well-characterized fauna. This locality, at Isla Vista in Goleta, California (near Santa Barbara), is a low-elevation marine-terrace deposit that was thought, on the basis of aminoacid ratios in fossil mollusks, to be on the order of ca. 50 ka (Wehmiller et al., 1977; Kennedy et al., 1982). This early age estimate is confirmed by a TIMS U-series age on a specimen of Balanophyllia elegans from the deposit, which is $47 \pm 0.5 \mathrm{ka}$ (Gurrola et al., 1996; Trecker et al., 1998), indicating a correlation with a relatively high (but lower than at present) sea stand within isotope stage 3 (Fig. 20). The fauna from this terrace has been well characterized by Wright (1972), who reported no extralimital southern species, but a number of extralimital northern species, including Macoma expansa, M. obliqua, Saxidomus gigantea, and Tresus capax (bivalves) as well as Lacuna carinata (a gastropod). Thus, the ca. $47 \mathrm{ka}$ fauna at Isla Vista indicates cooler-than-modern waters, which is in broad agreement with both the alkenone and planktonic foraminiferal records (Fig. 20). 


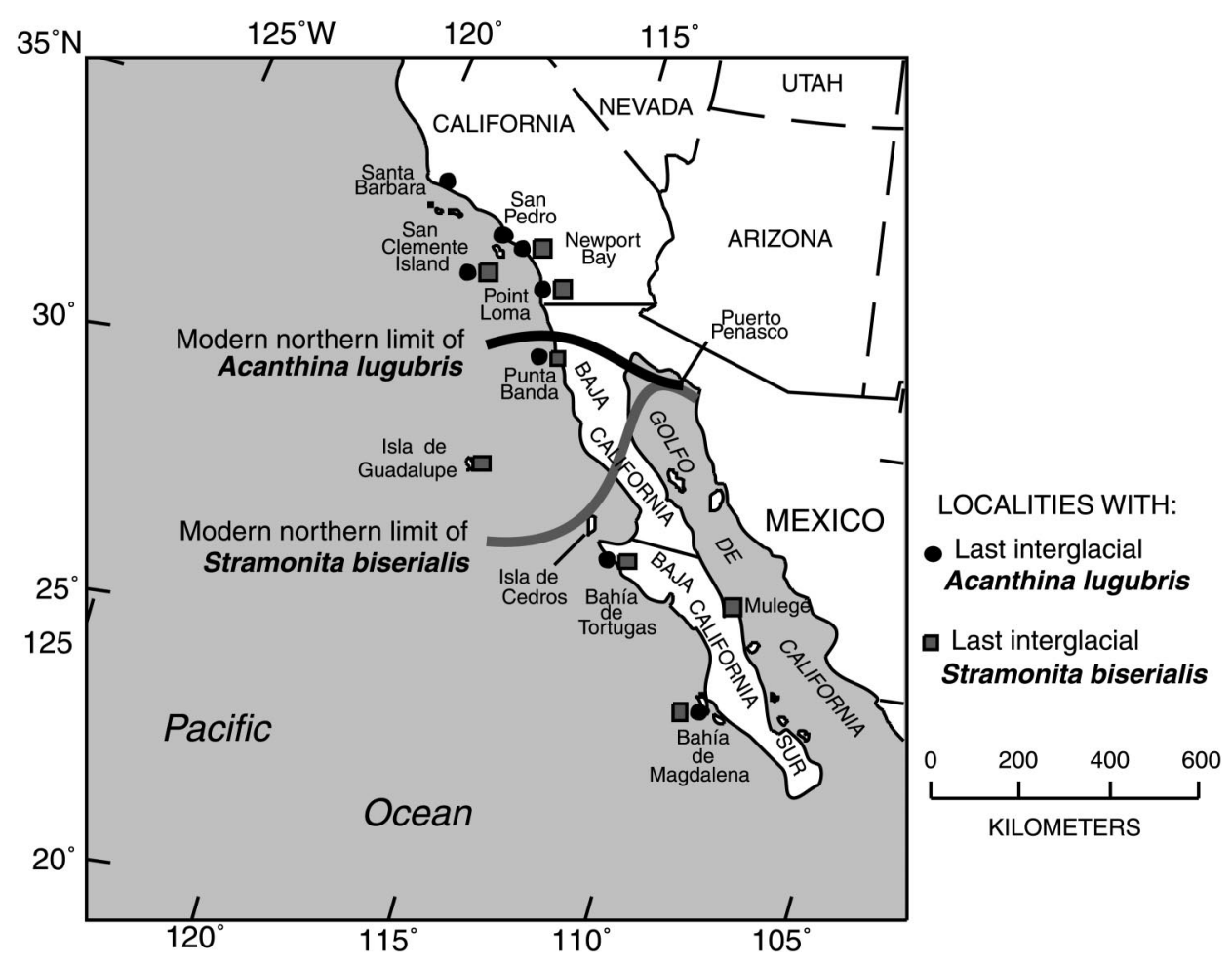

Figure 19. Map of southern California and Baja California showing the modern northern limits of two warm-water species, Stramonita biserialis and Acanthina lugubris, and terrace deposits containing these species that date or probably date to ca. 120 ka. Modern northern limits for Acanthina lugubris are from Rockwell et al. (1989) for the Pacific Coast and from L. Groves (Los Angeles County Museum of Natural History, 2001, written commun.; specimen record LACM 68565) and S. Walker (University of Georgia, 2001, written commun.) for the Gulf of California. Modern northern limits for Stramonita biserialis are from Keen (1971) for the Pacific Coast and from L. Groves (Los Angeles County Museum of Natural History, 2001, written commun.; specimen record LACM 22832) for the Gulf of California. Terrace faunas of last interglacial age that contain these species are from sources as follows: (1) Santa Barbara area-age and faunal data from Kennedy et al. (1992); (2) San Pedro area-faunal data from Valentine (1962), age data from Muhs et al. (1992); (3) Newport Bay—faunal data from Kanakoff and Emerson (1959), age data from Grant et al. (1999); (4) San Clemente Island-faunal and age data from this study; (5) Point Loma-faunal data from Valentine and Meade (1961) and Kern (1977), age data from this study; (6) Punta Banda-faunal data from Rockwell et al. (1989), age data from this study; (7) Isla de Guadalupe-faunal data from Lindberg et al. (1980), age data from this study; (8) Bahía de Tortugas-faunal and age data from Emerson et al. (1981); (9) Bahía de Magdalena—faunal data from Jordan (1936), age data from Omura et al. (1979); (10) Mulegé-faunal data from Ortlieb (1987), age data from Ashby et al. (1987).

\section{CONCLUSIONS}

1. The solitary coral Balanophyllia elegans, which ranges along the Pacific Coast of North America, takes up $\mathrm{U}$ in isotopic equilibrium with seawater during growth. After death, but before emergence, additional $U$ is taken up from seawater. Thus, these corals can be used for U-series dating by using all prior criteria for closed-system conditions, with the exception of $\mathrm{U}$ content.

2. Results of U-series analyses of corals from the Cayucos (central California) and Nestor (San Diego) terraces show an opensystem history, similar to what has been reported by other workers for these terraces. However, analyses of larger suites of corals and a model of continuous, secondary $U$ and
Th uptake show that despite the open-system conditions, two age groups of corals are present, probably representing the ca. 105 and ca. 120 ka sea-level highstands reported elsewhere.

3. Corals from San Clemente Island, California, and Punta Banda and Isla de Guadalupe, Baja California, show closed-system history and probably yield reliable ages. The peak last interglacial sea-level highstand is represented by terrace deposits at all of these localities, and corals have a range of ages from ca. 128 to $114 \mathrm{ka}$. In addition, two lower terraces are found on Punta Banda, and the lowest of these has corals with reliable ages of ca. $83-80 \mathrm{ka}$.

4. U-series ages of last interglacial corals from the Pacific Coast overlap with, but are on average younger than, corals from Barbados, the Bahamas, and Hawaii. This age difference is explained by the nature of the geomorphic response to sea-level change: Fringing or barrier reefs on low-latitude coastlines have "keep-up" corals with accretionary growth that can keep pace with rising sea level, whether on a tectonically rising or stable coastline. In contrast, midlatitude, high-energy coastlines undergo platform cutting during the early part of a sea-level highstand. On such coastlines, sediment and fossil deposition take place as sea level starts to recede. Nevertheless, the youngest ages of corals from San Clemente Island and Punta Banda overlap with the intermediate-aged and younger corals in Hawaii and the Bahamas and suggest that sea level was still relatively high at ca. 116 


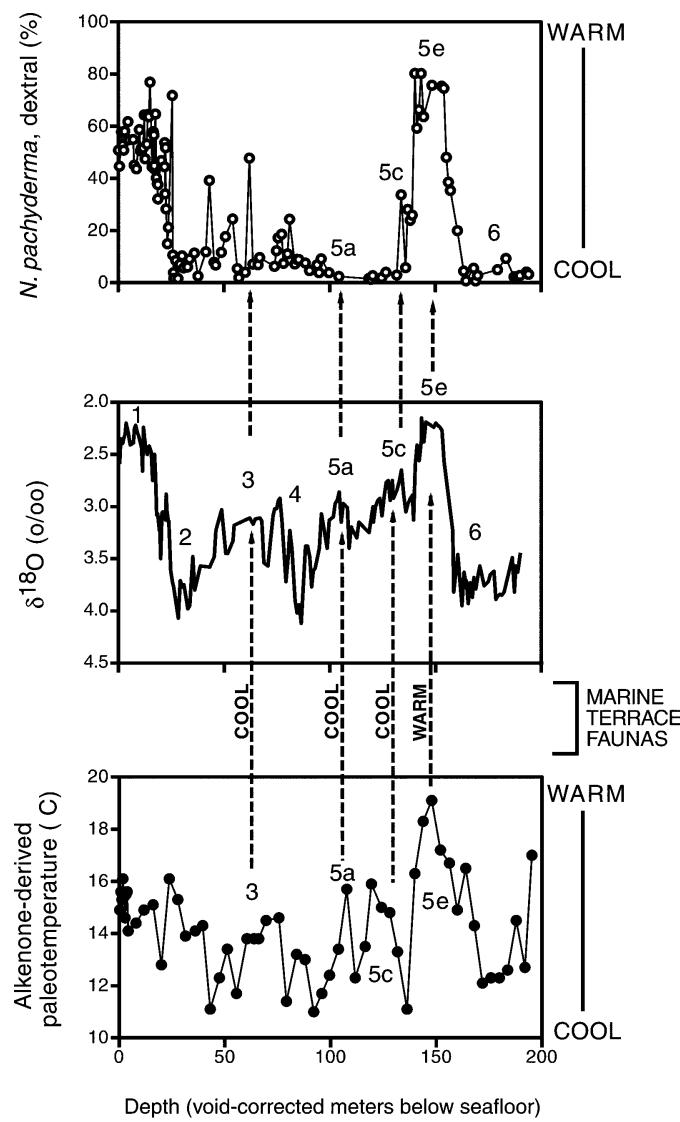

Figure 20. Paleoclimatic records from sediments of Santa Barbara Basin compared to marine-terrace faunas from this study. Middle panel: Oxygen isotope record of benthic foraminifera and isotope substages (data from Kennett, 1995). Upper panel: Abundances of warm-water planktonic foraminifer Neogloboquadrina pachyderma, dextral-coiling (data from Kennett and Venz, 1995). Lower panel: Surface-water paleotemperature estimates derived from alkenone-unsaturation index from phytoplankton (data from Herbert et al., 1995). Marine-terrace-fauna temperature aspect derived from paleozoogeographic inferences and $U$-series ages herein (see text for references).

ka. This finding conflicts with estimates of a relatively large global ice volume during isotope substage $5 \mathrm{~d}$, a time of low summer insolation at high latitudes in the Northern Hemisphere.

5. Fossil mollusks from reliably dated, ca. $120 \mathrm{ka}$ marine-terrace deposits include extralimital southern species that indicate ocean temperatures as warm as, or warmer than present. Northward range extensions (compared to the present range) were as much as 300 $600 \mathrm{~km}$ and may have been due to a weaker California Current and a stronger flow of tropical eastern Pacific waters northward. In contrast, ca. 80 ka marine deposits reported here and elsewhere have extralimital northern species indicating cooler-than-modern water temperatures. The presence of both ca. $105 \mathrm{ka}$ and ca. 120 ka corals on the Nestor and Cayucos terraces may explain the previously enigmatic

\section{ACKNOWLEDGMENTS}

This study was supported by the Earth Surface Dynamics Program of the U.S. Geological Survey and is a contribution to the LITE (Last Interglacial: Timing and Environment) Project. We thank the U.S. Navy and U.S. Coast Guard, and R.J. Dow and A. Yatsko III in particular, for access to and logistical support on San Nicolas Island, San Clemente Island, and Point Loma. Living corals were kindly provided by J.T. Carlton, J.H.R. Goddard, K. Scherer, R.W. Schmieder, and G. Van Blaricom. T.A. Deméré and E.C. Wilson allowed us to analyze additional fossil corals under their care at the San Diego Society of Natural History and the Los Angeles County Museum of Natural History, respectively. L. Groves identified some of the San Clemente Island mollusks. L. Groves, H.W. Chaney, and S. Walker kindly provided valuable information on the modern geographic distribution of certain mollusks. G. Skipp X-rayed the corals for aragonite purity. J. Wehmiller, P. Carrara, D. Belknap, and T. Ager read an earlier version of the paper and made very helpful comments for its improvement.

\section{REFERENCES CITED}

Abbott, R.T., 1974, American seashells: The marine Mollusca of the Atlantic and Pacific Coasts of North America (second edition): New York, Van Nostrand Reinhold Company, 663 p.

Aharon, P., and Chappell, J., 1986, Oxygen isotopes, sea level changes and the temperature history of a coral reef environment in New Guinea over the last $10^{5}$ years: Palaeogeography, Palaeoclimatology, Palaeoecology, v. 56, p. 337-379.

Arnold, R., 1903, The paleontology and stratigraphy of the marine Pliocene and Pleistocene of San Pedro, California: Memoirs of the California Academy of Sciences, v. 3, 420 p.

Ashby, J.R., Ku, T.L., and Minch, J.A., 1987, Uranium series ages of corals from the upper Pleistocene Mulegé terrace, Baja California Sur, Mexico: Geology, v. 15, p. $139-141$.

Bandy, O.L., 1968, Paleoclimatology and Neogene planktonic foraminiferal zonation: Giornale di Geologia, v. 35 , p. $277-290$.

Bard, E., Hamelin, B., and Fairbanks, R.G., 1990, U-Th ages obtained by mass spectrometry in corals from Barbados: Sea level during the past 130,000 years: Nature, v. 346, p. 456-458.

Bender, M.L., Fairbanks, R.G., Taylor, F.W., Matthews, R.K., Goddard, J.G., and Broecker, W.S., 1979, Uranium-series dating of the Pleistocene reef tracts of Barbados, West Indies: Geological Society of America Bulletin, Part I, v. 90, p. 577-594.

Berger, A., and Loutre, M.F., 1991, Insolation values for the climate of the last 10 million years: Quaternary Science Reviews, v. 10, p. 297-317.

Bloom, A.L., and Yonekura, N., 1985, Coastal terraces generated by sea-level change and tectonic uplift, in Woldenberg, M.J., ed., Models in geomorphology: Winchester, Massachusetts, Allen and Unwin Inc., p. 139-153.

Bloom, A.L., Broecker, W.S., Chappell, J.M.A., Matthews, R.K., and Mesolella, K.J., 1974, Quaternary sea level fluctuations on a tectonic coast: $\mathrm{New}{ }^{230} \mathrm{Th} /{ }^{234} \mathrm{U}$ dates from the Huon Peninsula, New Guinea: Quaternary Research, v. 4, p. 185-205.

Bradley, W.C., and Griggs, G.B., 1976, Form, genesis, and deformation of central California wave-cut platforms: Geological Society of America Bulletin, v. 87, p. 433-449.

Broecker, W.S., 1998, The end of the present interglacial: How and when?: Quaternary Science Reviews, v. 17, p. 689-694.

Broecker, W.S., Thurber, D.L., Goddard, J., Ku, T.-L., Matthews, R.K., and Mesolella, K.J., 1968, Milankovitch 
hypothesis supported by precise dating of coral reefs and deep-sea sediments: Science, v. 159 , p. 297-300.

Buddemeier, R.W., and Smith, S.V., 1988, Coral reef growth in an era of rapidly rising sea-level: Coral Reefs, v. 7, p. 51-56.

Chappell, J., and Shackleton, N.J., 1986, Oxygen isotopes and sea level: Nature, v. 324, p. 137-140.

Chen, J.H., Edwards, R.L., and Wasserburg, G.J., 1986, ${ }^{238} \mathrm{U},{ }^{234} \mathrm{U}$, and ${ }^{232} \mathrm{Th}$ in seawater: Earth and Planetary Science Letters, v. 80 , p. 241-251.

Chen, J.H., Curran, H.A., White, B., and Wasserburg, G.J., 1991, Precise chronology of the last interglacial period: ${ }^{234} \mathrm{U}-{ }^{230} \mathrm{Th}$ data from fossil coral reefs in the Bahamas: Geological Society of America Bulletin, v. 103 , p. $82-97$

Cheng, H., Edwards, R.L., Hoff, J., Gallup, C.D., Richards, D.A., and Asmerom, Y., 2000, The half-lives of uranium-234 and thorium-230: Chemical Geology, v. 169 , p. $17-33$.

CLIMAP Project Members, 1984, The last interglacial ocean: Quaternary Research, v. 21, p. 123-224.

Coan, E.V., Scott, P.V., and Bernard, F.R., 2000, Bivalve seashells of western North America: Marine bivalve mollusks from Arctic Alaska to Baja California: Santa Barbara, California, Santa Barbara Museum of Natural History Monographs, no. 2, 764 p.

Collins, L.B., Zhu, Z.R., Wyrwoll, K.-H., Hatcher, B.G., Playford, P.E., Chen, J.H., Eisenhauer, A., and Wasserburg, G.J., 1993, Late Quaternary evolution of coral reefs on a cool-water carbonate margin: The Abrolhos carbonate platforms, southwest Australia: Marine Geology, v. 110, p. 203-212.

Dodge, R.E., Fairbanks, R.G., Benninger, L.K., and Maurrasse, F., 1983, Pleistocene sea levels from raised coral reefs of Haiti: Science, v. 219, p. 1423-1425.

Durham, J.W., 1980, A new fossil Pocillopora (coral) from Guadalupe Island, Mexico, in Power, D.M., ed., The California islands, Proceedings of a multidisciplinary symposium: Santa Barbara, California, Santa Barbara Museum of Natural History, p. 63-70.

Edwards, R.L., Chen, J.H., Ku, T.-L., and Wasserburg, G.J., 1987, Precise timing of the last interglacial period from mass spectrometric determination of thorium230 in corals: Science, v. 236, p. 1547-1553.

Edwards, R.L., Cheng, H., Murrell, M.T., and Goldstein, S.J., 1997, Protactinium-231 dating of carbonates by thermal ionization mass spectrometry: Implications for Quaternary climate change: Science, v. 276, p. 782-786.

Emerson, W.K., Kennedy, G.L., Wehmiller, J.F., and Keenan, E., 1981, Age relations and zoogeographic implications of late Pleistocene marine invertebrate faunas from Turtle Bay, Baja California Sur, Mexico: Nautilus, v. 95 , p. $105-116$.

Fairbanks, R.G., and Matthews, R.K., 1978, The marine oxygen isotope record in Pleistocene coral, Barbados, West Indies: Quaternary Research, v. 10, p. 181-196.

Gallup, C.D., Edwards, R.L., and Johnson, R.G., 1994, The timing of high sea levels over the past 200,000 years: Science, v. 263, p. 796-800.

Gerrodette, T., 1979, Equatorial submergence in a solitary coral, Balanophyllia elegans, and the critical life stage excluding the species from shallow water in the south: Marine Ecology-Progress Series, v. 1, p. 227-235.

Grant, L.B., Mueller, K.J., Gath, E.M., Cheng, H., Edwards, R.L., Munro, R., and Kennedy, G.L., 1999, Late Quaternary uplift and earthquake potential of the San Joaquin Hills, southern Los Angeles basin, California: Geology, v. 27, p. 1031-1034.

Gurrola, L.D., Chen, J.H., Keller, E.A., and Metcalf, J.G., 1996, Dating of emergent marine terraces and rate of uplift for the western Santa Barbara fold belt, California: Geological Society of America Abstracts with Programs, v. 28 , no. 7 , p. 301 .

Hamelin, B., Bard, E., Zindler, A., and Fairbanks, R.G., $1991,{ }^{234} \mathrm{U} /{ }^{238} \mathrm{U}$ mass spectrometry of corals: How accurate is the U-Th age of the last interglacial period?: Earth and Planetary Science Letters, v. 106, p. 169-180.

Herbert, T.D., Yasuda, M., and Burnett, C., 1995, Glacialinterglacial sea-surface temperature record inferred from alkenone unsaturation indices, Site 893, Santa
Barbara Basin, in Kennett, J.P., Baldauf, J.G., and Lyles, M., eds., Proceedings of the Ocean Drilling Program, Scientific results, Leg 146: College Station, Texas, Ocean Drilling Program, v. 146, part 2, p. $257-264$

Herbert, T.D., Schuffert, J.D., Andreasen, D., Heusser, L., Lyle, M., Mix, A., Ravelo, A.C., Stott, L.D., and Herguera, J.C., 2001, Collapse of the California Current during glacial maxima linked to climate change on land: Science, v. 293, p. 71-76.

Hubbs, C.L., and Roden, G.I., 1964, Oceanography and marine life along the Pacific Coast of middle America, in Wauchope, R., ed., Natural environment and early cultures: Austin, Texas, University of Texas Press, Handbook of middle American Indians, v. 1, p. $143-186$

Jordan, E.K., 1936, The Pleistocene fauna of Magdalena Bay, Lower California: Stanford, California, Stanford University, Contributions of the Department of Geology, v. 1, p. 101-173.

Kanakoff, G.P., and Emerson, W.K., 1959, Late Pleistocene invertebrates of the Newport Bay area, California: Los Angeles County Museum Contributions in Science, no. $31,47 \mathrm{p}$.

Kaufman, A., Ghaleb, B., Wehmiller, J.F., and Hillaire-Marcel, C., 1996, Uranium concentration and isotope ratio profiles within Mercenaria shells: Geochronological implications: Geochimica et Cosmochimica Acta, v. 60 , p. $3755-3746$.

Kay, E.A., 1979, Hawaiian marine shells: Honolulu, Hawaii, Bernice P. Bishop Museum Special Publication, v. 64 , no. 4,653 p.

Keen, A.M., 1971, Sea shells of tropical west AmericaMarine mollusks from Baja California to Peru (second edition): Stanford, California, Stanford University Press, $1064 \mathrm{p}$.

Kennedy, G.L., 1978, Pleistocene paleoecology, zoogeography and geochronology of marine invertebrate faunas of the Pacific Northwest Coast (San Francisco Bay to Puget Sound) [Ph.D. thesis]: Davis, University of California, $824 \mathrm{p}$.

Kennedy, G.L., 2000, Zoogeographic correlation of marine invertebrate faunas, in Noller, J.S., Sowers, J.M, and Lettis, W.R., eds., Quaternary geochronology: American Geophysical Union Reference Shelf, no. 4, p. 413-424.

Kennedy, G.L., Lajoie, K.R., and Wehmiller, J.F., 1982, Aminostratigraphy and faunal correlations of late Quaternary marine terraces, Pacific Coast, USA: Nature, v. 299 , p. $545-547$.

Kennedy, G.L., Wehmiller, J.F., and Rockwell, T.K., 1992, Paleoecology and paleozoogeography of late Pleistocene marine-terrace faunas of southwestern Santa Barbara County, California, in Fletcher, C.H., III, and Wehmiller, J.F., eds., Quaternary coasts of the United States: Marine and lacustrine systems: SEPM (Society for Sedimentary Geology) Special Publication 48, p. 343-361.

Kennedy, G.L., Adler, J.A., and Rockwell, T.K., 1995, Middle and late Pleistocene neotectonic activity and sea level history: The marine terrace record on San Clemente Island, southern California: Geological Society of America Abstracts with Programs, v. 27, no. 6, p. A-375.

Kennett, J.P., 1976, Phenotypic variation in some Holocene and late Cenozoic planktonic foraminifera, in Hedley, R.H., and Adams, C.G., eds., Foraminifera, Volume 2: New York, Academic Press, p. 111-170.

Kennett, J.P., 1995, Latest Quaternary benthic oxygen and carbon isotope stratigraphy: Hole 893A, Santa Barbara basin, California, in Kennett, J.P., Baldauf, J.G., and Lyles, M., eds., Proceedings of the Ocean Drilling Program, Scientific results, Leg 146: College Station, Texas, Ocean Drilling Program, v. 146, part 2, p. 3-18.

Kennett, J.P., and Venz, K., 1995, Late Quaternary climatically related planktonic foraminiferal assemblage changes: Hole 893A, Santa Barbara Basin, California, in Kennett, J.P., Baldauf, J.G., and Lyles, M., eds., Proceedings of the Ocean Drilling Program, Scientific results, Leg 146: College Station, Texas, Ocean Drilling Program, v. 146, part 2, p. 281-293.

Kern, J.P., 1977, Origin and history of upper Pleistocene marine terraces, San Diego, California: Geological Society of America Bulletin, v. 88, p. 1553-1566.

Kern, J.P., and Rockwell, T.K., 1992, Chronology and deformation of marine shorelines, San Diego County, California, in Fletcher, C.H., III, and Wehmiller, J.F. eds., Quaternary coasts of the United States: Marine and lacustrine systems: SEPM (Society for Sedimentary Geology) Special Publication 48, p. 377-382.

Kreitz, S.F., Herbert, T.D., and Schuffert, J.D., 2000, Alkenone paleothermometry and orbital-scale changes in sea-surface temperature at Site 1020, northern California margin, in Lyle, M., Koizumi, I., Richter, C., and Moore, T.C., Jr., eds., Proceedings of the Ocean Drilling Program, Scientific results, Leg 167: College Station, Texas, Ocean Drilling Program, v. 167, p. $153-161$.

$\mathrm{Ku}$, T.-L., 1968, Protactinium 231 method of dating coral from Barbados Island: Journal of Geophysical Research, v. 73, p. 2271-2276.

$\mathrm{Ku}$, T.-L., and Kern, J.P., 1974, Uranium-series age of the upper Pleistocene Nestor terrace, San Diego, California: Geological Society of America Bulletin, v. 85, p. $1713-1716$

Ku, T.-L., Ivanovich, M., and Luo, S., 1990, U-series dating of last interglacial high sea stands: Barbados revisited: Quaternary Research, v. 33, p. 129-147.

Kukla, G.J., 2000, The last interglacial: Science, v. 287 , p. $987-988$

Kukla, G., McManus, J.F., Rousseau, D.-D., and Chuine, I., 1997. How long and how stable was the last interglacial?: Quaternary Science Reviews, v. 16, p. 605-612.

Lajoie, K.R., Ponti, D.J., Powell, C.L., II, Mathieson, S.A., and Sarna-Wojcicki, A.M., 1991, Emergent marine strandlines and associated sediments, coastal California: A record of Quaternary sea-level fluctuations, vertical tectonic movements, climatic changes, and coastal processes, in Morrison, R.B., ed., Quaternary nonglacial geology: Conterminous U.S.: Boulder, Colorado, Geological Society of America, Geology of North America, v. K-2, p. 190-203.

Lindberg, D.R., Roth, B., Kellogg, M.G., and Hubbs, C.L., 1980, Invertebrate megafossils of Pleistocene (Sangamon interglacial) age from Isla de Guadalupe, Baja California, Mexico, in Power, D.M., ed., The California islands, Proceedings of a multidisciplinary symposium: Santa Barbara, California, Santa Barbara Museum of Natural History, p. 41-62.

Lorenz, F., and Hubert, A., 2000, A guide to worldwide cowries (second edition): Hackenheim, Germany, Conch Books, 584 p.

Ludwig, K.R., Simmons, K.R., Szabo, B.J., Winograd, I.J., Landwehr, J.M., Riggs, A.C., and Hoffman, R.J., 1992, Mass-spectrometric ${ }^{230} \mathrm{Th}^{234} \mathrm{U}-{ }^{238} \mathrm{U}$ dating of the Devils Hole calcite vein: Science, v. 258, p. 284-287.

Ludwig, K.R., Muhs, D.R., Simmons, K.R., Halley, R.B., and Shinn, E.A., 1996, Sea level records at ca. $80 \mathrm{ka}$ from tectonically stable platforms: Florida and Bermuda: Geology, v. 24, p. 211-214.

Lynn, R.J., 1967, Seasonal variation of temperature and salinity at 10 meters in the California Current: California Cooperative Oceanic Fisheries Investigations Reports, v. 11, p. $157-186$

Mangelsdorf, K., Guentner, U., and Rullkoetter, J., 2000 Climatic and oceanographic variations on the California continental margin during the last $160 \mathrm{kyr}$ : Organic Geochemistry, v. 31, p. 829-846.

Martinson, D.G., Pisias, N.G., Hays, J.D., Imbrie, J., Moore, T.C., Jr., and Shackleton, N.J., 1987, Age dating and the orbital theory of the ice ages: Development of a high-resolution 0-300,000-year chronostratigraphy: Quaternary Research, v. 27, p. 1-29.

McManus, J.F., Bond, G.C., Broecker, W.S., Johnsen, S. Labeyrie, L., and Higgins, S., 1994, High-resolution climate records from the North Atlantic during the last interglacial: Nature, v. 371, p. 326-329.

Mesolella, K.J., Matthews, R.K., Broecker, W.S., and Thurber, D.L., 1969, The astronomical theory of climatic change: Barbados data: Journal of Geology, v. 77, p. $250-274$.

Mix, A.C., 1992, The marine oxygen isotope record; constraints on timing and extent of ice growth events 
(120-65 Ka): Geological Society of America Special Paper 270, p. 19-30.

Muhs, D.R., 1982, A soil chronosequence on Quaternary marine terraces, San Clemente Island, California: Geoderma, v. 28, p. 257-283.

Muhs, D.R., 1983, Quaternary sea-level events on northern San Clemente Island, California: Quaternary Research, v. 20, p. 322-341.

Muhs, D.R., and Szabo, B.J., 1982, Uranium-series age of the Eel Point terrace, San Clemente Island, California: Geology, v. 10, p. 23-26.

Muhs, D.R., and Szabo, B.J., 1994, New uranium-series ages of the Waimanalo Limestone, Oahu, Hawaii: Implications for sea level during the last interglacial period: Marine Geology, v. 118, p. 315-326.

Muhs, D.R., Rosholt, J.N., and Bush, C.A., 1989, The uranium-trend dating method: Principles and application to southern California marine terrace deposits: Quaternary International, v. 1, p. 19-34

Muhs, D.R., Kelsey, H.M., Miller, G.H., Kennedy, G.L., Whelan, J.F., and McInelly, G.W., 1990, Age estimates and uplift rates for late Pleistocene marine terraces: Southern Oregon portion of the Cascadia forearc: Journal of Geophysical Research, v. 95, p. 6685-6698.

Muhs, D.R., Miller, G.H., Whelan, J.F., and Kennedy, G.L., 1992, Aminostratigraphy and oxygen isotope stratigraphy of marine-terrace deposits, Palos Verdes Hills and San Pedro areas, Los Angeles County, California, in Fletcher, C.H., III, and Wehmiller, J.F., eds., Quaternary coasts of the United States: Marine and lacustrine systems: SEPM (Society for Sedimentary Geology) Special Publication 48, p. 363-376.

Muhs, D.R., Ludwig, K.R., Halley, R.B., and Shinn, E.A., 1994a, Extended duration of peak last-interglacial sealevel high-stand from uranium-series ages of corals and ooids from the Bahamas: American Quaternary Association Program and Abstracts of the 13th Biennial Meeting, p. 234

Muhs, D.R., Kennedy, G.L., and Rockwell, T.K., 1994b, Uranium-series ages of marine terrace corals from the Pacific Coast of North America and implications for last-interglacial sea level history: Quaternary Research, v. 42 , p. $72-87$.

Muhs, D.R., Simmons, K.R., and Steinke, B., 2002, Timing and warmth of the last interglacial period: New Useries evidence from Hawaii and Bermuda and a new fossil compilation for North America: Quaternary Science Reviews, in press.

Neumann, A.C., and MacIntyre, I., 1985, Reef response to sea level rise: Keep-up, catch-up or give-up: Moorea, French Polynesia, Antenne Muséum-Ephe, Proceedings of the Fifth International Coral Reef Congress, v. 3 , p. $105-110$

O'Clair, R.M., and O'Clair, C.E., 1998, Southeast Alaska's rocky shores: Animals: Auke Bay, Alaska, Plant Press, $561 \mathrm{p}$.

Omura, A., Emerson, W.K., and Ku, T.L., 1979, Uraniumseries ages of echinoids and corals from the upper Pleistocene Magdalena terrace, Baja California Sur, Mexico: Nautilus, v. 94, p. 184-189.

Ortlieb, L., 1987, Néotectonique et variations du niveau marin au Quaternaire dans la région du Golfe de Californie, Méxique: Paris, Institut Français de Recherche
Scientifique pour le Développement en Coopération, Collection Études et Thèses, 1036 p.

Ota, Y., and Omura, O., 1992, Contrasting styles and rates of tectonic uplift of coral reef terraces in the Ryukyu and Daito Islands, southwestern Japan: Quaternary International, v. 15/16, p. 17-29.

Rockwell, T.K., Muhs, D.R., Kennedy, G.L., Hatch, M.E., Wilson, S.H., and Klinger, R.E., 1989, Uranium-series ages, faunal correlations and tectonic deformation of marine terraces within the Agua Blanca fault zone at Punta Banda, northern Baja California, Mexico, in Abbott, P.L., ed., Geologic studies in Baja California: Los Angeles, Pacific Section, Society of Economic Paleontologists and Mineralogists, p. 1-16.

Rockwell, T.K., Nolan, J.M., Johnson, D.L., and Patterson, R.H., 1992, Ages and deformation of marine terraces between Point Conception and Gaviota, western Transverse Ranges, California, in Fletcher, C.H., III, and Wehmiller, J.F., eds., Quaternary coasts of the United States: Marine and lacustrine systems: SEPM (Society for Sedimentary Geology) Special Publication 48, p. 333-341.

Roy, K., Jablonski, D., and Valentine, J.W., 1995, Thermally anomalous assemblages revisited: Patterns in the extraprovincial latitudinal range shifts of Pleistocene marine mollusks: Geology, v. 23, p. 1071-1074.

Shackleton, N.J., 1987, Oxygen isotopes, ice volume and sea level: Quaternary Science Reviews, v. 6, p. $183-190$.

Squires, D.F., 1959, Results of the Puritan-American Museum of Natural History expedition to western Mexico. 7. Corals and coral reefs in the Gulf of California: Bulletin of the American Museum of Natural History, v. 118 , p. $367-432$.

Stein, M., Wasserburg, G.J., Lajoie, K.R., and Chen, J.H., 1991, U-series ages of solitary corals from the California coast by mass spectrometry: Geochimica et Cosmochimica Acta, v. 55, p. 3709-3722.

Stein, M., Wasserburg, G.J., Aharon, P., Chen, J.H., Zhu, Z.R., Bloom, A., and Chappell, J., 1993, TIMS Useries dating and stable isotopes of the last interglacial event in Papua New Guinea: Geochimica et Cosmochimica Acta, v. 57, p. 2541-2554.

Stirling, C.H., Esat, T.M., McCulloch, M.T., and Lambeck, K., 1995, High-precision U-series dating of corals from Western Australia and implications for the timing and duration of the last interglacial: Earth and Planetary Science Letters, v. 135, p. 115-130.

Stirling, C.H., Esat, T.M., Lambeck, K., and McCulloch, M.T., 1998, Timing and duration of the last interglacial; evidence for a restricted interval of widespread coral reef growth: Earth and Planetary Science Letters, v. 160 , p. $745-762$.

Szabo, B.J., 1985, Uranium-series dating of fossil corals from marine sediments of southeastern United States Atlantic Coastal Plain: Geological Society of America Bulletin, v. 96, p. 398-406.

Szabo, B.J., Ludwig, K.R., Muhs, D.R., and Simmons, K.R., 1994, Thorium-230 ages of corals and duration of the last interglacial sea-level high stand on Oahu, Hawaii: Science, v. 266, p. 93-96.

Trecker, M.A., Gurrola, L.D., and Keller, E.A., 1998, Oxygen-isotope correlation of marine terraces and uplift of the Mesa Hills, Santa Barbara, California, USA, in Stewart, I.S., and Vita-Finzi, C., eds., Coastal tecton- ics: Geological Society of London Special Publication 146 , p. $57-69$.

Valentine, J.W., 1958, Late Pleistocene megafauna of Cayucos, California and its zoogeographic significance: Journal of Paleontology, v. 32, p. 687-696.

Valentine, J.W., 1961, Paleoecologic molluscan geography of the Californian Pleistocene: University of California Publications in Geological Sciences, v. 34 , p. $309-442$.

Valentine, J.W., 1962, Pleistocene molluscan notes. 4. Older terrace faunas from Palos Verdes Hills, California: Journal of Geology, v. 70, p. 92-101.

Valentine, J.W., 1966, Numerical analysis of marine molluscan ranges on the extratropical northeastern Pacific shelf: Limnology and Oceanography, v. 11, p. 198-211.

Valentine, J.W., and Meade, R.F., 1961, Californian Pleistocene paleotemperatures: University of California Publications in Geological Sciences, v. 40, p. 1-45.

Vedder, J.G., and Norris, R.M., 1963, Geology of San Nicolas Island, California: U.S. Geological Survey Professional Paper 369, p. 1-65.

Veeh, H.H., and Valentine, J.W., 1967, Radiometric ages of Pleistocene fossils from Cayucos, California: Geological Society of America Bulletin, v. 78, p. 547-550.

Wehmiller, J.F., Lajoie, K.R., Kvenvolden, K.A., Peterson, E., Belknap, D.F., Kennedy, G.L., Addicott, W.O., Vedder, J.G., and Wright, R.W., 1977, Correlation and chronology of Pacific Coast marine terrace deposits of continental United States by fossil amino acid stereochemistry-Technique evaluation, relative ages, kinetic model ages, and geologic implications: U.S Geological Survey Open-File Report 77-680, 196 p.

Wehmiller, J.F, Krantz, D.E., Simmons, K.R., Ludwig, K.R., Markewich, H.W., Rich, F., and Hulbert, R.C., Jr., 1997, U.S. Atlantic Coastal Plain late Quaternary geochronology: TIMS U-series coral dates continue to indicate $80 \mathrm{kyr}$ sea level at or above present: Geological Society of America Abstracts with Programs, v. 29 , no. 6 , p. 346 .

Wilson, E.C., 1988, The hermatypic coral Pocillopora at Cabo San Lucas, Mexico: Bulletin of the Southern California Academy of Sciences, v. 87, p. 79-83.

Woodring, W.P., 1935, Fossils from the marine Pleistocene terraces of the San Pedro Hills, California: American Journal of Science, v. 29, p. 292-305.

Woodring, W.P., 1957, Marine Pleistocene of California, in Hedgpeth, J.W., ed., Treatise on marine ecology and paleoecology: Geological Society of America Memoir 67 , p. $589-597$

Woodring, W.P., Bramlette, M.N., and Kew, W.S.W., 1946, Geology and paleontology of Palos Verdes Hills, California: U.S. Geological Survey Professional Paper 207, 145 p.

Wright, R.H., 1972, Late Pleistocene marine fauna, Goleta, California: Journal of Paleontology, v. 46, p. 688-695.

Zhu, Z.R., Wyrwoll, K.H., Collins, L.B., Chen, J.H., Wasserburg, G.J., and Eisenhauer, A., 1993, High-precision U-series dating of last interglacial events by mass spectrometry: Houtman Abrolhos Islands, Western Australia: Earth and Planetary Science Letters, v. 118, p. 281-293.

Manuscript Received by the Society April 18, 2001 ReVised Manuscript Received November 21, 2001 MANUSCRIPT ACCEPTED November 27, 2001

Printed in the USA 